San Jose State University

SJSU ScholarWorks

Master's Theses

Master's Theses and Graduate Research

1991

\title{
The Culpability of James VI of Scotland, later James I of England, in the North Berwick witchcraft trials of 1590-91
}

Margaret Carol Kintscher

San Jose State University

Follow this and additional works at: https://scholarworks.sjsu.edu/etd_theses

\section{Recommended Citation}

Kintscher, Margaret Carol, "The Culpability of James VI of Scotland, later James I of England, in the North Berwick witchcraft trials of 1590-91" (1991). Master's Theses. 248.

DOI: https://doi.org/10.31979/etd.t27u-s5fk

https://scholarworks.sjsu.edu/etd_theses/248

This Thesis is brought to you for free and open access by the Master's Theses and Graduate Research at SJSU ScholarWorks. It has been accepted for inclusion in Master's Theses by an authorized administrator of SJSU ScholarWorks. For more information, please contact scholarworks@sjsu.edu. 


\section{INFORMATION TO USERS}

This manuscript has been reproduced from the microfilm master. UMI films the text directly from the original or copy submitted. Thus, some thesis and dissertation copies are in typewriter face, while others may be from any type of computer printer.

The quality of this reproduction is dependent upon the quality of the copy submitted. Broken or indistinct print, colored or poor quality illustrations and photographs, print bleedthrough, substandard margins, and improper alignment can adversely affect reproduction.

In the unlikely event that the author did not send UMI a complete manuscript and there are missing pages, these will be noted. Also, if unauthorized copyright material had to be removed, a note will indicate the deletion.

Oversize materials (e.g., maps, drawings, charts) are reproduced by sectioning the original, beginning at the upper left-hand corner and continuing from left to right in equal sections with small overlaps. Each original is also photographed in one exposure and is included in reduced form at the back of the book.

Photographs included in the original manuscript have been reproduced xerographically in this copy. Higher quality 6" x 9" black and white photographic prints are available for any photographs or illustrations appearing in this copy for an additional charge. Contact UMI directly to order.

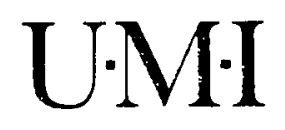

University Microfilms International

A Bell \& Howell Information Company

300 North Zeeb Road. Ann Arbor. Mi 48106-1346 USA

$313: 761-4700 \quad 800: 521.0600$ 
$\because$

-

- - - n 
The culpability of James VI of Scotland, later James I of England, in the North Berwick witchcraft trials of 1590-91

Kintscher, Margaret Carol, M.A.

San Jose State University, 1991

Copyright (C)1992 by Kintscher, Margaret Carol. All rights reserved.

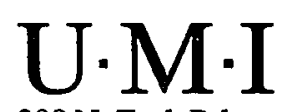

300 N. Zeeb Rd.

Ann Arbor, MI 48106 


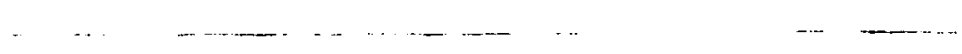


THE CULPABILITY OF JAMES VI OF SCOTLAND, LATER JAMES I OF ENGLAND, IN THE NORTH BERWICK WITCHCRAFT TRIALS OF 1590-91

\author{
A Thesis \\ Presented to \\ The Faculty of the Department of Social Science \\ San Jose State University
}

In Partial Fulfillment

of the Requirements for the Degree

Master of Arts

By

Margaret Carol Kintscher

December 1991 
APPROVED FOR THE DEPARTMENT OF SOCIAL SCIENCE

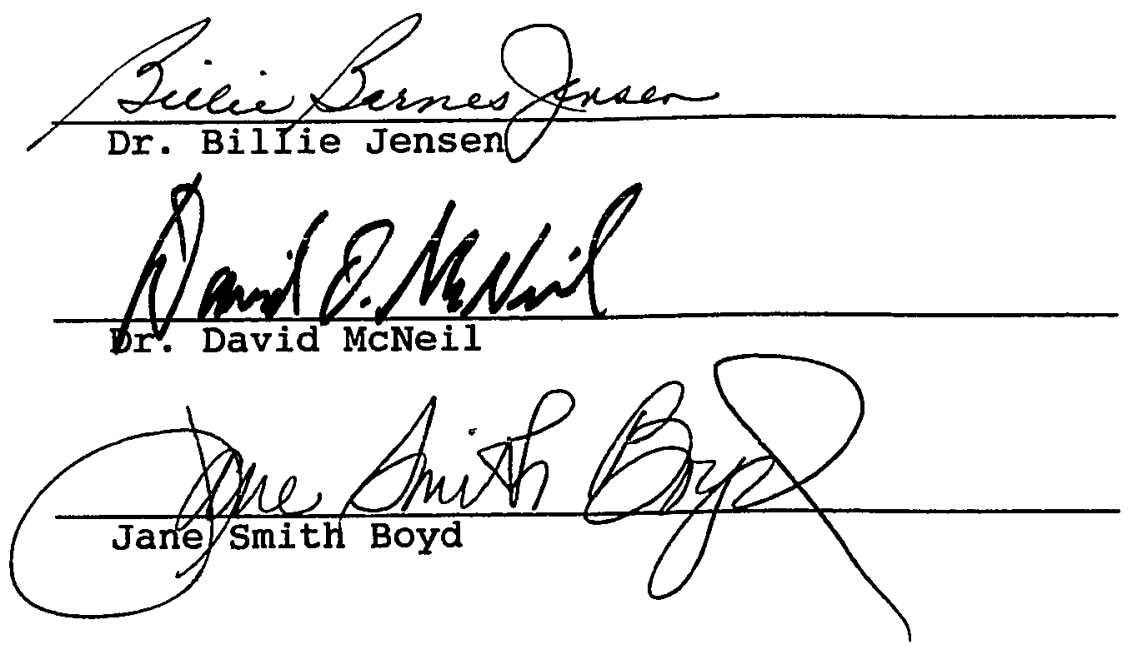

APPROVED FOR THE UNIVERSITY

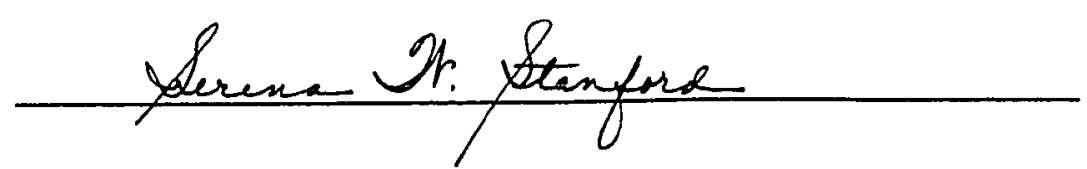


ABSTRACT

THE CULPABILITY OF JAMES VI OF SCOTLAND, LATER JAMES I OF ENGLAND, IN THE NORTH BERWICK WITCHCRAFT TRIALS OF 1590-91

by Margaret Carol Kintscher

This thesis examines the use of the North Berwick witchcraft trials by James VI of scotland to control his enemies, family, and people. This paper approaches the analysis of the accused as victims and not as perpetrators. They are examined here from a feminist framework of women's oppression: political, economic, and social. They were targets of oppression because they were midwives and healers, Catholics, and friends and employees of the Earl of Bothwell, the principal accused.

Research into the actual charges convicting the accused and James VI's speeches and letters reveals an underlying plot by Chancellor John Maitland and James VI to consolidate royal power and bring scotland from a feudal state to the modern world of the Tudor and Stuart national monarchy. Through these trials James VI introduced the Devil's mark and the Devil's pact, both of which sanctioned the inquisitor's mental and physical rape of women. Witchcraft was a woman's crime. Of the six principals accused in the trials, four were women and of the sixty-four recorded accused, fifty-one were women. 


\section{contents}

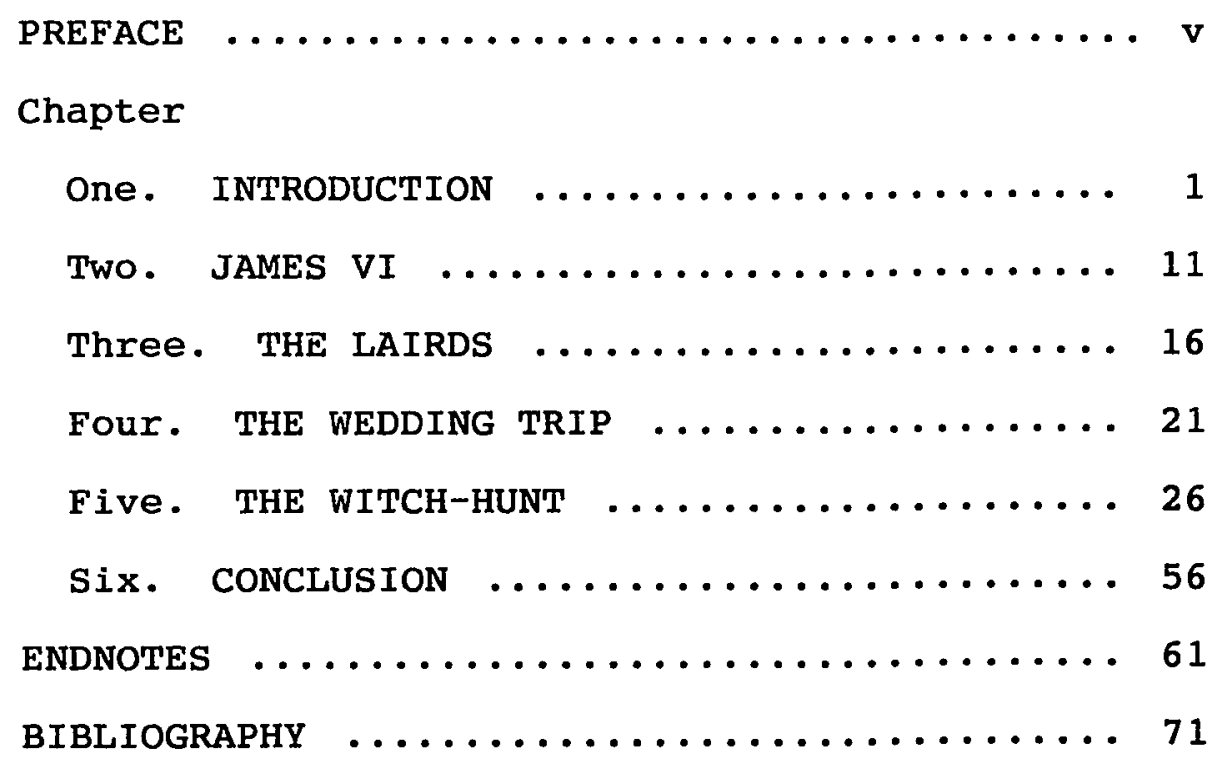




\section{PREFACE}

Women's Week, 1984, was my Rite of Passage from the world of passivity to the world of active feminism. For the first time $I$ was introduced to the harmful effects of pornography, sexual abuse, job discrimination, physical abuse, and other issues relating to women. How could I be so totally oblivious to women's problems? My only answer is that I was raised to distrust women and consider them as rivals. My goal in life was marriage and a family, which would claim my total loyalty. I believed women could not be trusted with anything or anyone. The concept of women as my sisters was totally foreign to me. Then on March 10, 1984, to quote anthropologist Dr. Roger D. Abraham, my everyday world was torn apart. I attended my first Women's Week events at San Jose State University.

Women's Week is a special time set aside by the University to provide a space where ideas and values that are different from those accepted by the wider society can be espoused. The week is planned, sponsored, and produced by the feminist group from the Women's Resource Center and the Women's Studies Department. All activities are planned and presented to bring women's issues and problems to the forefront of the University's and the greater community's 
awareness. Each day has a theme, and Saturday's theme was Women's Sexuality.

That evening Not a Love Story: a Film about Pornography by Canadian filmmaker Bonnie Sherr Klein was scheduled. The film covered a wide range of topics, including discussion and interpretation by psychologists, social scientists, and authors of various books on pornography. The film began with a tour of Toronto's burlesque clubs and establishments selling milder erotica, and progressed to hard-core pornography that left me shaken and nauseated. One particular misogynistic scene still haunts me: a naked woman lies on a bare wooden table, her arms and legs tightly bound and a ball taped in her mouth. Her captor, dressed in black leather mask and armor is placing clothespins on the nipples of her tightly bound, purpling breasts. The man's head and body are encased in leather with metal spikes and studs so that his leering mouth is the only visible part of his face. His penis is erect and long, encased in a leather shield with spikes protruding from the sides. The writhing woman, with her silenced screams and wild, terrified, pain-filled eyes was not an actress. She was a "sex slave" who had been kidnapped, and then raped, tortured, and murdered on film, so the filmmakers could sell the copies at $\$ 1,500$ each on the underground pornography market. 
I chose to describe this film clip in detail because eventually I came to understand it as related to the torture, rape and murder of hundreds of thousands of women accused of practicing witchcraft and demonology by both the Catholic and Protestant Churches and the state governments of the Early Modern period of our western European History.

After the film, we were led on a "Take Back the Night" march. We yelled out our frustration and pain, and felt empowered by action. The ceremony that closed the week's events was held on the Quad in front of Morris Daily Auditorium near the fountain. It was led by several women wearing long, flowing, hooded gowns belted with rope. We were instructed to hold hands and form a circle. There were approximately fifty women and ten men. The men were asked to form their own circle, separate from the women. We were each given a candle to hold. One woman entered the circle and called out the names of witches and goddesses, telling their stories as she named them. I was surprised and incredulous for, after all, this was a college campus. Another woman joined her and held a knotted rope aloft. She explained that the knot represented women's bondage and we must all work to break it. She loosened the knot and we lit our candles. Each candle was held by two people, keeping the circle intact. Then, circling slowly, we sang songs of liberation and chants about goddesses. When the chanting stopped, the circle was broken, and we were invited to hug 
each other. A robed woman passed a platter of sugar cookies and another woman carried a large goblet of punch. We ate and drank, a form of communion. The candles were extinguished. The evening was over. Several months later I learned that I had attended my first witches' esbat. ${ }^{1}$

This was my first awareness of women as sisters, not rivals, and that fall I entered the Women's Studies Program. My first two classes in Women's Studies were "Perspectives on Sex Roles" with Jane Smith Boyd and "Gods and Goddesses" with Carol Christ. Jane introduced me to a totally different way of viewing men's and women's roles, while Carol opened my world to the Goddess religions of Old Europe and the New Feminist Spirituality. Jane was the first to teach me that witches were not evil old hags trying to destroy good christians. She taught me that witches were not Satanists but generally they were just harmless old women, midwives, and rebels. I wrote my first paper exploring the history of the Early Modern witch-hunts for Jane's class, and thus began my quest to find out the truth of what happened during those trials and burnings and to relate those findings to what is still happening today. My research has led me to conclude that we may never know what really happened. We may never find the "truth" because every village in every country had a different reason for hunting witches and just about every author and historian has a different theory of why. I have read books 
and articles by historians, anthropologists, feminists, theologians, sociologists, and psychologists. Each field has a different theory and each writer in each field has a different theory. These theories comprise a vast field of reasons from economics, misogyny, medicine, social unrest, changing religions, plague, jealousy, sexual repression, and just plain fear.

My special thanks go to my thesis committee for their support: Jane Smith Boyd for introducing me to witches as victims and teaching me about power and its uses; to David McNeil who shares my interest in the European witch-hunts; to Billie Jensen who constantly asked "Well, have you started writing, yet?" Without Billie's question, I would probably still be reading. My special, special thanks goes to the employees of the Clark Library Inter-Library Loan office without whom I could never have found copies of books, pamphlets, letters, and tracts written four hundred years ago. Using a Dictionary of the older Scottish Tongue I was able to read those pamphlets and tracts specifically about James VI and the North Berwick trials and piece together the story without using another author's interpretation.

This research has provided me with a focus for analyzing James VI's involvement in the trials as persecutor and not victim. Most historians try to portray James VI as an unwilling participant in the North Berwick trials, 
especially the English authors who either briefly mention the trials or totally ignore them. They accept the fact of a diabolical plot against James. My goal was to investigate these trials from a different viewpoint. I maintain that the real victims of the trials were the accused and not James. James used these people to destroy his enemies by launching the first great witch-hunt in scotland. 


\section{Chapter one}

\section{INTRODUCTION}

James VI of Scotland, later James I of England, considered himself a demonologist and proudly labeled himself "The Witch Hunter." In 1589 he became involved in a political witch-hunt that ruled his life for three years and totally transformed witchcraft trials in Scotland and, later, in England, by introducing demonology and the use of the Devil's pact as evidence to gain convictions. He participated in the torture of the accused and interfered in their trials if they were acquitted. ${ }^{2}$ James was the first ruler of a country to substantiate demonology and witchhunting and Matthew Hopkins, the famous English witchhunter, admitted that he based his hunting on James' book, the Daemonologie, In Forme of a Dialogue. ${ }^{3}$ I will discuss the Daemonologie later in my analysis of James' culpability in the North Berwick trials.

In the fall of 1589 , Princess Anne of Denmark sailed from Norway to join her new husband, James VI of Scotland. Her ships were prevented from landing in scotland by contrary winds and storms. James sailed to Norway to "rescue" his bride. After spending the winter in Norway, 
James and Anne sailed to scotland in the spring of 1590 . Again, their ships were assailed by heavy storms and contrary winds. James firmly believed that over two hundred women and men were the instruments in the Devil's conspiracy to prevent his bride from reaching scotland and, later, to kill him in the spring of 1590. His involvement in witchhunting continued into his reign in England where, in 1604, he supported and demanded a new Witchcraft Act, overriding the more liberal Act of 1563. Some historians claim James was losing his interest in witchcraft and demonology by the time he went to England because he waited a year to change the Witchcraft Act of 1563. The most likely reason he waited was that intense heat had "swelled" the plague in London and the Parliament was not called until 1604.4 James changed the death penalty to include those who used witchcraft for the first time, whereas the original Act had decreed the death penalty only for the second or the third use. He also introduced to English law the Devil's pact and the keeping of familiars, which were first introduced in Britain at the North Berwick trials. These trials were well documented because Scotland was entering the modern world of literacy, record-keeping and printing, and because James wanted to become the heir to Elizabeth I of England's throne. Elizabeth had already become irate after the Scots minister, John Knox, published his The First Blast of the Trumpet against The Monsterous 
Regiment of Women, and several historians believe that James wrote the Daemonologie to validate his personal involvement in the tortures and the trials of the victims, mostly women. Elizabeth was furious because Knox claimed that women "had no talent for ruling,"s and she had forbidden Knox entrance into England when he became a refugee from the Scottish Reformation. James' dislike of women was common knowledge in both Scotland and England at that time, and today James is considered one of the greatest misogynists of all time. The purpose of this paper is to examine the North Berwick trials. I limited my research to the years 1589 to 1592, including James' wedding to Anne of Denmark, his trip to Norway and Denmark, the storms that started the rumors of witchcraft, the witch-hunt itself, and the writing of the Daemonologie. Whereas the Daemonologie was published in 1597, I will show that it was actually written during the North Berwick trials. The thesis of this paper is to illustrate that James VI, an erudite genius, tried to control his enemies, his family, and his people by starting and directing the North Berwick witchcraft trials, the first of the great Scottish witch-hunts, and that the accused were chosen for who they were, not because they were witches. There is a vast amount of research covering European witch-hunts, and Jeffrey Burton Russell divides that research into four major interpretations. His first interpretation is the liberal view that witchcraft never 
existed but was created by the Church authorities to "enhance their powers and enlarge their purses." The second is the Murrayite tradition, composed of the followers of the late anthropologist Margaret Murray, claiming that witchcraft is a survival of the ancient fertility cults involving sexual liaisons between the Goddess and the Horned God. The third interpretation emphasizes the social patterns of witch accusations, blaming superstitions rather than the Church, while the fourth emphasizes that witchcraft is a history of ideas and concepts assembled over many centuries. ${ }^{6}$ All four interpretations are correct within the limits of incompatibility with each other, and need to be broadened to include two further interpretations: the first is that the victims of witchcraft accusations were Satanists following the Devil, and the second, that the witch-hunts were created to control and subjugate women in a world ruled by patriarchy. The latter group includes many educated and respected feminist researchers and authors, in addition to many radical feminist authors, whose efforts the present writer hopes to supplement.

Just as feminists can be divided into separate branches of the women's movement, so the feminist interpretations of the witch-hunts of Early Modern Europe can be divided into separate groups: liberal, spiritual, and radical. The liberal feminists combine Russell's first, third, and fourth interpretations of witchcraft research in scholarly books 
and articles. This group includes Sally Smith Boothe, Mary Douglas, Rosalind K. Marshall, and Antonia Fraser. ${ }^{7}$ The spiritual feminist writers follow Margaret Murray's theory of a surviving ancient fertility cult; however, Murray developed her theory over sixty years ago and many historians, mostly male, have tended to denigrate her research and call her a fraud. Today, the spiritual feminist interpretations are based on the new research of the Goddess religions of Old Europe by James Mellaart, Marija Gimbutas, Ruby Rohrlich, Carol Christ, Charlene Spretnak, Barbara Walker, and Gerda Lerner. The last group, the radical feminist authors, interpret the witch-hunts as a patriarchal, woman-hating phenomenon. This group includes Mary Daly, Andrea Dworkin, Mathilda Joselyn Gage, Selma R. Williams, Elizabeth Cady Stanton, and Pamela J. Williams. The earlier famous female historians of witchcraft are not feminist in their interpretations. This group includes Christina Larner, Venetia Newall, Katherine Briggs, and Barbara Rosen. These last four authors may have been feminists, sirce they were strong, active women scholars, but their interpretations are not from a feminist perspective regarding inequality and injustice. Christina Larner, considered the leading authority on Scottish witchcraft, flatly denied that the Scottish witch-hunts were in any way misogynistic. She stated that "the crime of witchcraft, while sex-related, was not sex-specific." She 
used the statistics that twenty per cent of the accused in both Great Britain and Continental Europe were male. ${ }^{8}$ She did not mention that ninety-five per cent of the accused in Scotland were female. Hugh V. McLachlan and Christopher Hyde Lee, who worked with Christina Larner to compile a list of Scottish witchcraft prosecutions from the early court records, proposed the figure to be eighty-six per cent female, but in ten per cent of the total cases they recorded the sex was not listed or the victims were listed as various witches" or as "Three or Four Witches" or their names were left blank. ${ }^{10}$ They based the eighty per cent figure on the statistical median of Scotland with ninety-five per cent women, England with seventy-six per cent women, and Continental Europe with ninety per cent women.

Larner claimed that the authorities were after witches "as such" and not specifically women. A witch's sin was that she or he renounced Christian baptism. Larner stated that the fact that eighty per cent of the victims were female "added fuel to the misogyny of the age" but was not a direct result of it. ${ }^{11}$ Very few historians of witchcraft consider it a sex-specific crime. They are afraid to connect the witch-hunts with the persecution of women because then they would have to admit that women specifically were persecuted. On the other hand, G.R. Quaife stated that witchcraft and infanticide were two crimes created to control women. Women committing these 
crimes were prosecuted and punished by the court systems, whereas with other crimes, they were delegated to the authority of their male relatives and guardians to be punished. In some places these male guardians continued to be held responsible for women's crimes until the nineteenth century. ${ }^{12}$

In the early Middle Ages men outlived women by twenty years, creating a population shortage where women were needed for breeding and, therefore, valued; however, by the twelfth century, improvement in life-style, curtailment of violence, and the protection of women from warfare lengthened the lifespans of women, causing their status to drop. The combination of the Black Death's killing more men than women and the emigration of men to the New World left a surplus of unmarried women in Europe. Some sought economic security and independence in the convents, but most were left as a burden on the communities. ${ }^{3}$ With their children emigrating to towns and leaving elderly relatives to survive on their own, and with the resultant later age marriages for women, many older women were left unattached to males in the farmlands and villages.

Witch-hunts were a legal means of controlling unattached and, therefore, uncontrolled women. The majority of women who were named witches were unattached to males, unmarried or widowed, and as such, were a threat to the male establishment and competed for inheritances and profits, 
especially in Scotland where the poverty level was so high that most males emigrated to the towns and emigrated to the New World. Selma Williams claimed the result was a "totally uncoordinated, though murderous war on women."14 The theory has been advanced that the medical profession, with the backing of the Church, tried to stop wise men and women from using herbal remedies and incantations to heal. Whereas some healers were charged and convicted, I doubt it was an organized plot to do away with women healers and midwives. According to the evidence, not enough of the victims were healers to substantiate the charge. Further evidence points to women on all levels of society being responsible herbalists and healers, especially the ladies of the castles who were responsible for the medical well-being of all those under their care, including villagers and tenants.

While this war on women witches may have been "totally uncoordinated," definite rules and procedures were, nevertheless, followed. By the end of the sixteenth century the pattern for accusations, inquisition, trial, and execution was set. The victim was accused by a neighbor or relative. She was tortured to confirm a confession already in existence before she was accused. Her trial followed a set pattern dictated by the Malleus Maleficarum. ${ }^{15}$ The influence of the Malleus Maleficarum in Scotland before 1590 is improbable since there is no mention of demonology in any witchcraft trials before the North Berwick trials on the 
judges' benches, and in most countries she was burned alive or strangled and then burned. A witch was burned because fire was the only way to completely stop her evil powers. The authorities claimed that once a witch was arrested she was powerless to harm her captors or accusers and the Devil was powerless to save her. This explained why helpless old women did not "bewitch" their captors.

The contents of the witches' confessions were set in detail by the Inquisitorial Process ${ }^{16}$ developed in the Middle Ages to try heretics, and the laws regarding the use of torture to confirm confessions were dictated by a special process set for witchcraft trials alone. In Scotland, torture was used only in cases of treason and at the command of the Privy Council (the king's advisory committee) or the king. Since central control of local authorities was hard to enforce, torture without warrant was often used in pretrial investigations. ${ }^{17}$ England did not allow the accused to be tortured before trial, but members of her family could be tortured in front of her. In England, the pact with the Devil was not mentioned in the trials until after James I's accession to the English throne in 1603. In Scotland, as in Continental Europe, the use of torture was prevalent, and the testimony against the witch including the Pact with the Devil was set by the Inquisitorial Process. Since Scottish law was based on the old Roman codes, and not on precedence as in England, evidence confirmed or elicited 
from torture could be used as testimony at trials. Generally, the accused was arrested and tortured by the Church and then remanded to the secular courts for execution. Special laws were passed to allow torture and to allow women to be prosecuted. Laws were created withholding the identity of the accusers. In Scotland, in 1591, a law was passed to admit evidence elicited from those not "normally thought fit to testify,"18 such as, women, insane persons, and the disreputable. Books written to enlighten the intelligentsia on demonology were not factors in Scottish witchcraft trials until the late sixteenth century, after the advent of the printing press. The demonologists, as these authors were called, were widely read, especially by the Church leaders, lawyers and judges, and notably, King James VI of Scotland. 


\title{
Chaptex Two
}

\section{JAMES VI}

\begin{abstract}
"Kings are justly called gods for that they exercise a manner of resemblance of divine power upon earth . . " stated James I of England to Parliament in $1610 .{ }^{19}$ James firmly believed that as God's Lieutenant on Earth, he, as a king, was of "the breathing images of God."20 He believed that his prerogative must prevail in all things and that to oppose him in anything was to show impiety and high contempt. He was a genius with many interests. He was erudite. He wrote and published many books and pamphlets. He took pleasure in learning and fancied himself a judge. He liked to attend trials, and though he did not interfere with most of them, ${ }^{21}$ James VI directly interfered in the North Berwick witchcraft trials when he returned from his trip to Norway and Denmark in 1590. The thesis of this paper is to show that the position of and the beliefs about women in Reformation Scotland allowed James VI, an erudite genius, to believe that there was a satanic conspiracy against him and to use his unique power as king to control his enemies, his family, and his people by starting and directing the North Berwick witchcraft trials.
\end{abstract}


James VI was often described as a coward, always fearful of death. He wore overstuffed clothes to guard against knife attacks. Considering the bloody history of James' predecessors and the circumstances of his birth and childhood, he had ample reason to fear assassination. James became king at the age of thirteen months when his mother, Mary Stuart, was forced to abdicate the throne and abandon him. Traditionally, at birth the princes and princesses of Scotland were placed under the governorship of the Earls of Mar. The Earl's household was severely Calvinist and the Lady Mar was a cold woman and extremely strict. James was afraid of her. His childhood bed was draped in black damask with pillows fringed in black. His one decoration was a picture of his grandfather, James $V$, above his bed.22 He never received, nor knew of, the toys and gifts his mother, Mary Stuart, sent him during her exile in England. At the age of six months, he suffered from rickets. ${ }^{23}$ For most of his life he had recurrent attacks of abdominal colic accompanied by nausea, fast and irregular pulse, weakness and spasms of his limbs. He suffered from bouts of unconsciousness, and his urine would turn red. The symptoms suggest he suffered from porphyria, a pathological state characterized by abnormalities of porphyrin metabolism caused by a need for more chlorophyll in the diet. 24

His childhood was haunted by the deaths of those around him. He grew up with the rumors that his mother had been 
responsible for his father's murder. His own birth was shrouded with "witchcraft." He was born with a caul, which the Scots called "holy or sely how."25 His mother suffered from a "long desperate labor." She was attended by the Countess of Athole, known for empathic healing. Mary told Andro Lundy that she had no pain of birth because the Lady Athole took the pain upon herself.26 James' ancestry was riddled with stories of prophecy and witchcraft. In 1437, James I was murdered at Perth. His death was predicted by an Irish witch. 27 James IV's defeat at Flodden was foretold by apparitions the night before the battle. ${ }^{28}$ James' own grandfather, James $V$, was visited by apparitions preceding his death.

James would have been well aware of his family's history and it is recorded that his tutor, George Buchanan, when displeased with him would call him "the true bird of the blood nest from which he sprang."zo Buchanan was well known for his hatred of Mary Stuart. Historically he is credited with writing the "Casket Letters" that caused Mary's beheading. ${ }^{30}$ James VI's own childhood was violent. His first regent, the Earl of Moray, was assassinated in 1570. The regency passed to his paternal grandfather, the Earl of Lennox, who died in a battle in september 1571. James, then four years old, witnessed the death. The Earl of Mar became regent and died of natural causes when James was seven years old. 31 According to Antonia Fraser, James 
was constantly being kidnapped by one faction or another because the possession of the king was the possession of power. An envoy from England described James as "having a remarkable intelligence, lofty and virtuous ideals, and a high opinion of himself." The writer continued that James was a "vieux jeune homme" (old young man) because of his "wary, sidelong glance and his disillusionment."32 At the age of thirteen years, James met Esme stuart, Seigneur D'Aubigny, a kinsman from France. D'Aubigny discussed diplomacy and politics with the lonely boy and introduced him to poetry and homosexual experience. James named him the new Earl of Lennox.33 When James was sixteen years old, jealous Scottish lords forced Lennox to leave Scotland in an incident called the Ruthven Raid. James was humiliated in public by his state ministers. ${ }^{34}$ He, also, learned that just because he was king, his version of a story would not necessarily be read from the pulpits. The ministers could refuse. 35

James was the first king of scotland to be educated to rule. His tutors were the two leading scholars of the day, George Buchanan and Peter Young. He received his religious training in a severe Calvinist form of the Scottish Protestant Church. His library consisted of over six hundred volumes. ${ }^{36}$ His school days were rigorous, and he found relief from the drudgery of his studies in an abnormal interest in the supernatural, in the "horrible and awful, in 
magic, in witchcraft, and in the freaks and monstrosities of nature."37 He was imbued with the notions of divine retribution, the distinction between the saved and the nonsaved, and the importance of grace. ${ }^{38}$

George Buchanan was not the source of James' beliefs in his divine right to rule. Buchanan taught James' that kings existed to serve the people who confer the power on the king and, therefore, are superior to the king.39 Nonetheless, at age twelve James decided that he was God's chosen on earth and ruled by the divine right of kings. James was never the father of his country, nor was he interested in being thought of as such. His image as a young impressionable innocent victim does not match the contemporary descriptions of him. Many of today's historians, especially the English, evidently cannot accept James' culpability in the North Berwick trials. They feel that the king of scotland would not participate in the tortures, nor interfere in the trials, of innocent people to consolidate his power and destroy his enemies. Yet, by 1589, James had three goals: to be the omnipotent ruler of Scotland, to bring scotland out of its feudal state and into the modern Elizabethan world, and to become the king of England. Those who stood in his way were expendable, and he was willing to use anyone he could to achieve those goals. 


\section{Chaptex Thxee}

\section{THE LAIRDS}

That witch-hunts occurred in times of great stress and unrest is generally accepted by both historians and anthropologists; however, for this theory to apply to Scotland there would have had to have been one continuous witch-hunt from the beginning. Scotland had a history of unrest and intrigue. The scottish lairds were continuously fighting and quarreling among themselves. In 1588, James began his campaign to break the power of the lairds. Helen Stafford points to the plotting of the Catholic Earls as one problem that may have set James on the path to witchhunting. The plotting was certainly distressing, but only different from the other squabbles of the lairds because Huntly, the leader, was very powerful and was considered the "king" of the North. Huntly and the other lairds had joined with Spain and France to restore Roman Catholicism as the state religion of Scotland. They were deeply involved with the Spanish Armada which sank off the coast of Britain in 1588, known as the Brig $0^{\prime}$ Dee Conspiracy. James had to break Huntly's power. Francis stewart 40 Hepburn, the fifth Earl of Bothwell, made his first big 
mistake by standing beside Huntly with the loyalty that James demanded for himself.41 James had to break the power of the lairds to control scotland and bring it into the modern age. As long as the country was being torn apart by these inner squabbles scotland would never become a united or powerful nation.

Scotland was the first European country to develop a sense of nationality. ${ }^{42}$ As a united people, they were Scottish first and Scots, Anglo-Saxons, Picts, Normans, Saxons, and celts second. Scotland was their home and their country. They were loyal to her first and the king was their symbol of unity. He was their father and they chose to love and protect him, but only as long as he minded his own business and left them alone. ${ }^{43}$ The lairds were the chiefs of their clans and homes. The peoples' loyalty was given to them first. When a man or woman chose a clan, he or she took that clan's name as his or her own.44 If the laird gave his loyalty to the king, the clan members followed him unquestioningly. When a woman married she kept the name of her clan. She was known by her given name, clan name, and then, "wife of . . . "45

James needed to destroy the Earls of Bothwell, Huntly, Argyle, Erroll, Moray, and the other lairds who essentially ruled the people of Scotland. Until James' rule, the king was seen as an ideal, an overseer of the affairs of the kingdom. He was an idealized focal point of the society. 
He was accessible to the people. He was their father. ${ }^{46}$ James was different. He wanted rule by the divine right of kings. He wanted to control his country and his people. Earlier kings did not try to control the nobility. They knew that to reduce the power of the lairds was to weaken the monarchy, so they tried to strengthen their personal relations with them. ${ }^{47}$ The lairds did not think of the king as a sovereign lord but as a feudal suzerain. They, themselves, were sovereigns in their own districts, summoning the whole countryside to arms at any time. They were at constant feud with each other. Crime was rife and men "set themselves to defend their kin against the courts of justice." Together John Maitland and James aimed to bring scotland into the modern world by forcing the lairds to obey the law, teaching the people to turn to the courts and not the lairds, and to enforce laws against guns. 48

The lairds were powerful and popular. Huntly, ruler of the North, was treacherous and cruel, and, though not known as a man of great ability, he was a competent military leader. He was credited with roasting his enemies alive and decorating his castle with the severed limbs of his foes.49 Bothwell was the most popular laird in scotland. The people protected and adored Bothwell. His father was an illegitimate son of James $v$, making him a claimant to the throne. James VI knew, by contrast, that his people did not like him because he was openly contemptuous of them. 
Bothwell was popular and James knew from Scottish history that popularity and strength were stronger issues in royal succession than blood ties.

Historically one laird gained the throne by stabbing the king at dinner and taking over. Maitland would not have had to work hard to convince James that Bothwell was a threat. James knew that Bothwell was ruthless. He was fierce and lawless. He was an outlaw who spent his time in carousals, feuds, and rebellions. Thomas Fowler, a contemporary observer, wrote that "There is more wickedness, more valor, and more good parts in him . . than in any three of the other noblemen."so James and Bothwell had quarreled the year before when Mary Stuart was beheaded by Elizabeih. James decided to do nothing to avenge the murder of his mother because he did not want to jeopardize his relationship with Elizabeth. Bothwell proclaimed himself the King's Defender and urged war.51 He scoffed at James' purple mourning clothes and declared the best suit of mourning was a suit of mail.52 Maitland made a plea to avenge Mary's death, but bowed to James' decision, while Bothwell joined the Brig $0^{\prime}$ Dee Conspiracy and tried to raise his Borderers ${ }^{53}$ against James. While James adored Bothwell, Maitland hated him. Willson claimed that Bothwell had joined the Brig $O^{\prime}$ Dee Conspiracy to ruin Maitland. Bothwell's hatred for Maitland supposedly began during a feud over the ownership of the priory of Haddington, which 
had belonged to Bothwell's father.54 The hatred between the two men was intense and Bothwell was resolved to go to any lengths to drive the Chancellor from power. James was caught in the middle. He needed Maitland because the Chancellor was a statesman. James realized that the Earl of Bothwell was a threat to everything he was trying to do for Scotland. James knew that Bothwell and the other lairds were anachronisms. He knew that even though he had stopped a Cathoilc Conspiracy, Huntly, Erroll, Argyle, and the others were still trying to bring scotland back to the Roman Catholic Church. They were conspiring with spain and France. Bothwell was helping them. Bothwell's reputation was militantly Protestant, yet the Earl was suspected of being Catholic. Bothwell and the conspirators surrendered to James at the Brig $0^{\prime}$ Dee Bridge, were imprisoned, tried for treason, pled guilty, and placed in easy confinement for a few months. When Bothwell openly supported Huntly and the Catholic Earls and stood beside Huntly before the King, Maitland saw his chance to destroy Bothwell's position with James. This was February 1589.55 


\section{Chapter Four}

\section{THE WEDDING TRIP}

James had to break the power of the lairds to gain the power he needed to rule Scotland. He and Maitland began the campaign to do so in the late 1580 s which culminated in both the Brig $O^{\prime}$ Dee Conspiracy and the North Berwick trials. 56 James incarcerated Huntly and the other conspirators in luxury and did little to punish them because he needed Huntly's power over the North. Even though these men plotted his overthrow as the means of returning scotland to Catholicism, James showed little concern and no real attempt to destroy them.57 The North Berwick trials, on the other hand, were different, because James could become involved both physically and intellectually in them. James needed Huntly and the other Earls, but except for Bothwell whose involvement emerged later in the trials, the North Berwick plot involved women and men who were not leaders of clans but midwives, wives of merchants or burghers, and laborers. These were people with no real power. They were safe victims. James could, and did, vent his anger on these people because they had no followers to rise against him. 
The Ruthven Raid, the Brig $0^{\prime}$ Dee Conspiracy, and the storms of his wedding trip were events that made him feel helpless in one way or another. All lessened his image of himself as God's Anointed, a view he had held since childhood.58 The North Berwick trials, by contrast, fed his ego, confirming his self-image as a hero, the survivor of a diabolical plot. He was, indeed, God's Anointed. The trials also destroyed a lot of the lairds' powers in its aftermath.

In 1589 , the need to assure the succession was foremost in the minds of the government and James. He decided that an alliance with Denmark was the most beneficial for Scotland and he negotiated for the hand of the eldest daughter of King Christian of Denmark. Ultimately he settled for the younger daughter, Anne, and on July 28, 1589, William Asheby, the English ambassador to Denmark, wrote "The King is but a cold wooer. He is not hasty of marriage."59 James disliked women, regarding them as inferior beings. He had no training in politeness and George Buchanan, his tutor, taught him that women did nothing but cause trouble and make cuckolds of their husbands.60 James considered males to be superior, he was openly homosexual, and he preferred the handsome young men of the court. He always had a favorite whom he showered with gifts and titles. 
On September 1, 1589, Queen Anne sailed for Scotland after having been married by proxy in the Lutheran rite. She set sail on the Gideon, the flagship of Admiral Peter Munk, along with thirteen other ships. The ships were racked by storms on the North sea and finally, because Anne was forbidden to return to Denmark without her husband, they turned to Norway where she stayed until James arrived to escort her to Scotland. Munk knew that the Gideon was too light because it had insufficient ballast. Timbers leaked and the hold flooded. After seven weeks of trying to gain the shore in Scotland, Munk turned back to Norway. ${ }^{61}$ At this time Munk claimed that the parsimony of the Danish treasurer, Christopher Walkendorp, was to blame. He had sent the ships to sea in an unseaworthy condition, and Munk and Walkendorp had a furious quarrel when Munk returned to Denmark. ${ }^{62}$

When news reached Scotland about Queen Anne's peril, James ordered national fasting and public prayers. Originally, Francis Stewart Hepburn, fifth Earl of Bothwell and Admiral of Scotland, was commissioned to bring the new queen to scotland. When Bothwell submitted an estimate of the cost of the journey, the Council refused to release the funds. Scotland was known for being poor. Chancellor Maitland, who disliked Bothwell, urged the king to go himself. When James consented to the great adventure of rescuing his bride, Maitland arranged for himself and other 
"loyal subjects" to incur the expense of the trip and provide the ships.63 James was afraid to leave Maitland and Bothwell in charge of scotland in his absence because they hated each other, so he insisted that the Chancellor accompany him. The king kept his trip a secret. Not even Bothwell knew he was going. ${ }^{64}$ James' departure was delayed by a severe storm, followed by four fair days. The fifth day the ship was driven ashore in Norway by the worst of the storms in an especially severe winter. After the poverty of Scotland where James had to borrow money from Elizabeth I of England to finance his marriage, James was delighted to spend the winter in Norway and Denmark being wined and dined in luxury.

James and Anne spent the winter in Denmark at the Danish Court. James occupied his time visiting Tycho Brahe, the astronomer and demonologist, Niels Hemmingsen, the famous Danish scholar and demonologist, and various Lutheran intellectuals.65 On April 21, 1590, James and Anne set sail for Scotland. Again the ships were wracked with storms, but they landed safely in Scotland.66 According to Newes from Scotland, a ship sent to meet the new queen carrying jewels and rich gifts was sunk by the storms.67 Since James and Scotland were poor, one wonders where these rich gifts came from. After all, Elizabeth had answered James' distress by providing his wedding clothes and he had to borrow from others to go to Denmark. At the time he left there was a 
battle going on over how to find the money to refurbish Holyrood House to make it habitable for Anne when there was no money in the treasury. ${ }^{68}$

Admiral Peter Munk is credited with starting the North Berwick trials with his suspicions that witches were the cause of the storms of 1589. The witch-hunt in Copenhagen did not start until the summer of 1590 when Munk accused Anna Koldings of raising the storms. Why did Munk wait a year to accuse Koldings? Did he switch from blaming Walkendorp to accusing witches because James and Maitland were now involved with their newfound knowledge of demonology? Munk's reason for accusing Anna Koldings was that a year before the Princess Anne left for Scotland, Munk had slapped Anna Koldings' husband in public. The storms were her revenge.69 In the summer of 1590 the news reached Scotland that Anna Koldings and nine other women were burned in Copenhagen. 


\section{Chapter Five}

\section{THE WITCH-HUN'T}

James was among the first kings to use the printing press to disseminate information on a large scale. He was a firm believer in the power of the pen and wrote letters, tracts and essays for publication. One of his most famous tracts was Newes from Scotland, Declaring the Damnable Life and Death of Doctor Fian, A Notable Sorcerer, who Was Burned at Edenbrough [sic] in January Last, 1590. James Melville, a member of James' court and an historian, wrote that the tract was written by James Carmichael, minister of Haddington.70 It was published in 1591. Carmichael had been commissioned by the king to write several items at that time, including a grammar. ${ }^{7 x}$ James ordered the pamphlet written in order to validate his involvement in the tortures and the trials of the victims accused in the North Berwick trials. He needed to explain his involvement to the English and to Queen Elizabeth I because he wanted to be named her heir.

Newes from Scotland, as it is commonly referred to, is a horror pamphlet that was written to praise James and reinforce his claim to being God's chosen. Much of the 
literature available on the North Berwick trials is based on this pamphlet which is assumed to be historically accurate because it was written contemporary to the trials. Yet, the pamphlet itself is filled with wild stories of enchanted cats, cows, and midnight meetings in churchyards. James, of course, comes across as the doubting victim who must be convinced of the truth of the plots. Larner claimed that the skeptical figure who was later convinced by some infallible proof is a standard feature of the tracts. ${ }^{72}$ We would do well to question why notable historians are willing to base their research on what we would classify a dubious source comparable with today's National Enquirer. Yet, due to the dearth of information readily available to the historian about these trials, Newes from Scotland is indeed the most quoted source.

Robert Pitcairn's Ancient Criminal Trials of Scotland is the second major source generally available to the researcher. The volumes consist of the dittays, or charges, of which the victims were convicted. Pitcairn published the original text of the indictments in the old scots tongue, with added historical information in his footnotes. The actual records of the trials have been lost. The major source of James' view of the conspiracy is contained in his "Tollbooth Speech," which is reproduced in Pitcairn's Ancient Criminal Trials of Scotland. The next largest source of information available on the trials can be found 
in the Calendar of State Papers, Scotland, 1589-1593 and The Border Papers, Volume I. There are also minor references to the trials in James Melville's Diary and his Memoirs, and in James' letters.

James ordered James Carmichael to write Newes from Scotland because he was busy writing the text of the Daemonologie and because the tract portrayed him in a way he could not credibly do himself. Most sources claim that the Daemonologie was written after the trials because it was published in 1597; however, the discovery of MS 1125.1 in the Folger Shakespeare Library in Washington which has marginal notes written in James' handwriting, led Rhodes Dunlap to conclude that the manuscript was written in 1591 and set asidt until it was printed in 1597.73

Most writers and historians, including Christina Larner, claim that James showed no interest in witchcraft until his visits with Tycho Brahe and Niels Hemmingsen and other prominent scholars, demonologists, and Lutheran religious leaders in Denmark. The discovery in 1590 of an organized plot by witches to kill him began the obsession with witch-hunting that occupied him for the next few years. He was proud of his title "Witch-Hunter," the man God chose to represent Him in Scotland. Larner based her theory of James' lack of interest on the omission of any identifiable material on demonology in his library. Larner's theory is faulty because James must have read Reginald Scot's 
Discovery of Witchcraft and Johann Weyer's De Praestigiis Daemonum because his Daemonologie is in fact a refutation and answer to those works. Since James claimed he was a Calvinist, he must have read John Calvin's works and Calvin covered witchcraft and demonology in his writings. Calvin's Institution is listed in the library contents. ${ }^{4}$ Both Calvin and Luther were actively involved in witchcraft persecutions. 75 Also, contained in James' library was a copy of La Republique by Jean Bodin. ${ }^{76}$ Bodin, a judge and demonologist, wrote De La Demonomanie des Sorciers, which was published in England during Elizabeth's reign and went through several printings, all in English. Bodin was in England during Mary Stuart's incarceration and openly supported her. ${ }^{77}$ James had read Jean Bodin's Demonomanie and Cornelius Agrippa's De occulta philosophia because he used both works as references in his the Daemonologie. ${ }^{78}$ James was interested in witches before he left for Denmark. In 1589, at Aberdeen, he sent for Marioune McIngaruch, a "notorious and rank" witch. She showed him three "stanis," or drinking-vessels, used in her art. ${ }^{79}$ she did not seem to be under arrest at that time because she was involved in the Hector Munro trial in 1590. Hector Munro was the stepson of Lady Fowlis, who was acquitted the year before of the murder of Robert Munro, her deceased husband's heir. Hector Munro was probably acquitted of the murder due to powerful family influence. Hector was McIngaruch's 
client and she was arrested at that time. ${ }^{\circ}$ During the Hector Munro trial, McIngaruch was questioned by the king. James did not fear her at that time, just five months before the North Berwick trials started. Her fate is listed as unknown in Larner's A Source-Book for Scottish Witchcraft; however, four of the non-gentry arrested in Munro's trial were burned at the stake. Since McIngaruch was a well-known witch who was not involved in the North Berwick trials, I conclude she must have been executed earlier. There were no official records of executions kept in scotland at that time. Whether a person was listed as executed or not was left to the discretion of the clerk. Generally, when an accused witch was burned, the clerk would go to the original dittays and write "weirrit and parit" (strangled and burned) in the margin, sometimes with a date.

The Munro trial occupied the summer of 1590 after James' return from his wedding trip. He was involved in the interrogations. The upper class principals were acquitted. Stafford claims that the information about the Copenhagen trials arrived in scotland that summer, specifically in July. In August, seven women were tried in Aberdeen for witchcraft and three of them were executed. Still, there was no mention of demonology in any of the trials.81 The Munro trial involved a family too powerful to be accused of demonology, and James was not involved in the Aberdeen trials. 
Witches in Scotland were often accused of raising or placating storms. Storm raising was prominent in the folklore and religions of scotland. While reading from the manuscripts of their patron saint Columba written in his own hand, the monks of Iona, Scotland's holy island, would shake the tunic in which he died three times in the air. They claimed this was always an effective way to gain both rain and an abundant harvest. ${ }^{82}$ In another part of Western Scotland, the inhabitants would lift the cover of a mystical well and scatter the water into the air to raise a fair wind. ${ }^{3}$ The Highlanders believed that to raise a storm, a witch needed to draw a cat through a fire and then throw it into the sea. ${ }^{-4}$ Therefore, James' search for the witches who raised the storms that prevented his Queen from reaching Scotland in September 1589, and his own return from Denmark in spring 1590, was based on historical precedent.

In the summer of 1590 , James became involved in the Munro witchcraft trial. In July, he learned of the Copenhagen storm-raising trials. Probably by November, David Seaton started the North Berwick persecutions; although the date for this is uncertain, Gelie Duncan's "confession" states she was involved in a witch's sabbath on October $31,1590.85$ David Seaton, deputy town bailiff of Trennent, answered James' inquiries about the possibility of witches raising storms in Scotland by torturing Gelie Duncan, his young maid servant. She was known for her 
"uncanny" ability to heal the sick and to bring comfort to the melancholy and grieving. ${ }^{86}$ Since healing was considered a miraculous act, uneducated Gelie could safely be accused of witchcraft. Seaton used the "pelliwinks" on Gelie's fingers and "winched" her head. ${ }^{\text {I }}$ Seaton did not torture Gelie to find out what she was doing at night. He already knew because she was known for her healing powers. Newes from Scotland stated that seaton tortured her to see if her powers came from the Devil. He also tortured her to find a connection between the storm raising and the king. Gelie withstood Seaton's crushing of her fingers and the winching. She refused to confess until they found the Devil's mark on her throat. ${ }^{88}$

The victim could withstand torture as long as she believed that God would protect her and she had the hope of going to heaven. People believed firmly that the innocent could not be harmed by torture because God would not allow it. The finding of the Devil's mark on the body of an accused witch was devastating to the victim. Gelie was stripped of her clothes in a room full of men. Her hair was shaved from her body as well as her head, and her body was minutely examined, especially her vagina and breasts. A large pin was inserted into any marks they found to see if they would bleed or were insensitive to pain, both signs of the Devil's mark. For a woman to be stripped of her clothes was unheard of in Early Modern Scotland. Women could not be 
hanged in the ordinary way because men might look up their skirts.89 So, if they had to be hanged, their skirts were tied closely around their legs. Nudity was deplored by the Catholic and Protestant churches, as was sex. For Gelie to be stripped of her clothes in a room full of men would have been as devastating to her as a gang rape would be to a woman today. Her subsequent confession to witchcraft and the pact with the Devil was an admission that would condemn her to eternal damnation.

Gelie's "confession" consisted of an elaborate tale of witches' sabbats and plots to kill the king. How did Gelie, a servant, a Highlander, and therefore, a Catholic,90know about demonology? Gelie's name is a clan name and most inhabitants of Lower Scotland were not Highlanders, but were descendants of invaders. As a Highlander in the Lowlands, Gelie Duncan faced discrimination and distrust. Highlanders were considered shiftless thieves and murderers. As late as the early seventeenth century, the Highlands were closed to Lowlanders. Even then, only a few merchants, clergy and military were allowed to travel there.91 Many Highland girls migrated to the Lowlands because of lack of employment in the Highlands.92 In the mid-eighteenth century nine out of ten Highland women still could not read. So we could interpret that Gelie Duncan could not read.93 Books were for the rich and Gelie Duncan could not have read about demonology . 
There is no record of demonology in scotland before John Cunningham's trial in which Gelie accused him and thirty-nine others. The Scottish people first learned about demonology from the reading of the dittays at John Cunningham's trial. R.A. Houston stated that gossip was the way of creating public opinion and sanctions against unconventional behavior. ${ }^{94}$ The common people learned news and information from pulpit sermons and from the dittays of trials. The authorities made deliberate efforts to educate the lower classes about demonology during the witch-hunts.95 The information on demonology that Gelie "confessed" to must have come from David Seaton. ${ }^{96}$ He, in turn, probably gained it from someone within the king's immediate circle because it is generally accepted that James brought that information into scotland from Denmark, and neither the Munro trial nor the Aberdeen trials had any mention of demonology.

In 1591, the Earl of Bothwell claimed that Maitland was the force behind the witchcraft accusations resulting in the North Berwick trials. Maitland, as James' chancellor, was helping James break the power of the lairds. Bothwell, the most popular laird in scotland, James" cousin and friend, and an heir to the throne. The connection between Gelie and the Earl is through the thirty-nine people she accused of treason against the king. Three of those people were friends of Bothwell's: John Cunningham, Barbara Napier, and Eufame MacCalzean; one, Niniane Chirnesyde, was Bothwell's 
servant.97 Bothwell was connected to Huntley and the Brig O' Dee Conspiracy. He openly stood beside Huntly against the king. John Cunningham was Bothwell's secretary.98 Agnes Sampson, Eufame MacCalzean and Barbara Napier were prominent Catholics.99

John Cunningham, more commonly known in witchcraft lore as the "Abominable Dr. Fian," was the schoolmaster at Saltpans in Lothian County, near Edinburgh. "John Fian" was, supposedly, his secret name used only with his fellow witches and given him by the Devil, or so Newes from

Scotland claimed. Helen stafford stated that Cunningham was intensely disliked by his neighbors for his ill temper and his philandering ways. Gelie's confession accused Cunningham of being the "register" of the witches, reading their names as recorded in the Devil's book, and the "onlie" man to come to their meetings. ${ }^{100}$ Yet, many claim that the Earl of Bothwell was the "black man" recorded in Newes from Scotland and in the other victim's confessions. Cunningham was arrested and taken to Holyrood House, where he was tortured in one room, then taken into another to be questioned by James. The king "took great delight to be present at the examinations." 101 Newes from Scotland detailed the tortures Cunningham endured. The preliminary processes were not considered torture. His head was winched. The author stated that they used "fair means" to elicit a confession, but Cunningham refused to confess. ${ }^{102}$ 
Since the preliminary questioning failed, they resorted to "real" torture. They used the boots. ${ }^{103}$ Newes from Scotland claimed he resisted confession until pins were found under his tongue and removed. He was committed to prison and the next day he renounced his wicked ways. That night he escaped.104 Newes from Scotland claimed he escaped alone by miraculously coming into possession of his cell key. Contemporary sources stated that Bothwell freed him. When Cunningham was recaptured, he recanted his confession. Newes from Scotland claimed they found no Devil's mark on John Cunningham when James had him searched, but the second charge of the dittays convicted him of having a Devil's mark.105 Cunningham's torture was continued, but he refused to confess. He was arraigned, convicted of twenty separate charges of witchcraft and treason, and sentenced to die. John Cunningham was strangled and then burned at Castle Hill in Edinburgh on a Saturday in January 1591.106

As with any witch, once John Cunningham was arrested, he lost his power to harm others. Therefore, James did not fear to participate in the interrogation of any accused witches. Since the torture of witches was not to elicit a confession but to corroborate the existing confession, James was assured of a conviction. Eleven of the twenty charges against Cunningham dealt with the threat to James' life. "It was only the piety of the king, as Dr. Fian admitted in his confession, that overmatched the power of the evil 
one."107 of all the North Berwick trial victims for which there are records, John Cunningham is the only accused to be known by his secret witch's name in the trial records. He has come down in history as the "Abominable Dr. Fian." How may we account for Dr. Fian's crime being remembered as more heinous than that of the other accused? Why was his trial first when Gelie Duncan was accused, arrested, and tortured first? John Cunningham was not related to anyone else in the case. Larner and other authorities are adamant that most males accused of witchcraft were related in some way to an accused woman herself, or by being associated through being her daughter, sister, or niece. ${ }^{108}$ John was not a practicing sorcerer. He was disliked, they claim, because of his womanizing, yet, womanizing was common and accepted in scotland. While it was common to accuse a woman of witchcraft because she was disliked, it was rare to accuse a man.

Why was John Cunningham accused of witchcraft? We might speculate that given James' contempt for the lack of intelligence in women, he could not believe that the plot against his life was instigated and carried out by women. This explanation is unlikely, given John Cunningham's connection to Bothwell. As Bothwell's secretary, he was the key to Maitland's destruction of the Earl. Yet, Bothwell's name was not mentioned in Cunningham's trial which ended December 26, 1590, even though Bothwell helped him escape 
during that trial. Nor was Bothwell mentioned in Agnes Sampson's trial which began on January 27, 1591.

Agnes Sampson, the Wise Wife of Keith, was a notable midwife and healer. James Melville described her as "most remarkable; a woman, not of the base and ignorant sort of Witches, but matron-like, grave and settled in her answers, which were all to some purpose."xos Agnes Sampson was a widow with children. She was poor and supported herself and her children with her healing abilities.110 After her arrest she was taken to Holyrood House, the King's castle in Edinburgh. There she was questioned by James and some of his nobles. She denied all charges of witchcraft. They used the thumbscrews to torture her. When she continued to deny the charges they shaved her body of all hair, looking for the Devil's mark. When they found it in her "privities," she broke and confessed to "whatsoever was demanded of her."111 Agnes Sampson's confirmation of her confession may have been no more than the sagging of her head, which was an accepted response and affirmation that confession was offered freely.112 Agnes, like Gelie Duncan and John Cunningham, "confessed" to witches' sabbats, pacts with the Devil, plots against the King's life and raising storms by throwing cats in the ocean. Newes from Scotland adds the additional charge of telepathy against her. When James doubted her story at the end of her trial, she took 
him aside and whispered in his ear the "exact conversation between himself and Anne on their wedding night in Oslo.113 Why would a woman of Agnes Sampson's standing in the community try to convince her king that she was a witch, knowing what her fate would be? When asked why James was protected from the power of her witchcraft she answered "Il est homme de Dieu." (He is a man of God.). James Melville records that these were words that she did not understand, but had memorized. ${ }^{114}$

Agnes Sampson was tried on January 27, 1591. There were so many dittays against her that the persons chosen for the Assize Court were sworn and then removed to another building where they voted on each charge. They pronounced her guilty of fifty-two of the dittays, acquitting her of one.115 She was strangled and burned at the stake on the same day as John Cunningham. "All her moveable goods [were] confiscated and paid to James."116

Agnes Sampson, even more than Gelie Duncan, fit the image of the witch that had evolved on Continental Europe. She was a widow, a midwife, a healer, and poor. Of the fifty-two dittays she was convicted of, thirty-six dealt with healing or mid-wifery. Before 1590, those accused of witchcraft were convicted of maleficium, or harming others. Agnes was convicted of helping or healing others through her prayers and knowledge. The difference lies in the new knowledge of the pact with the Devil. 
Agnes was arrested because she was a member of the cunning-folk, who were believed to be taught by God or aided by the angels.117 Their ability to heal their fellows was miraculous and often contributed to God's working through them. Both the Protestant and Catholic Churches tried to destroy the cunning-folk by linking their healing powers with the Devil. In reality, the people continued to turn to the local healers because charms and prayers were better than the prospect of surgery, which usually meant amputation, or the use of purges and vomits. The mortality rate of doctors' patients was high.118 The Church taught that illness was God's visitation and death was specific judgment from God.119 Keith Thomas stated that the witches provided comfort and assistance, both physical and psychological, where the Church and doctors failed. George Gifford, in his Dialogue Concerning Witches published in 1593, declared that the local wise woman "doeth more good in one year than all these scripture men will do so long as they live."120

To counter the powers of the wise women and men, the law and the Church gave the helpless a way to get revenge for the loss of a loved one. The bereaved could prosecute the "witch" and the law would execute her.121 In Scotland, the Church prosecuted and the law executed. By forbidding the use of the Latin Paternosters, the Virgin Mary, the intervention of the saints, and the use of creeds to heal, 
the Protestants proclaimed that only God could perform a miraculous cure. For Agnes Sampson to attempt to heal her clients through her prayers was a misuse of miraculous power. Since Agnes was a woman, and uneducated, her power could only come from the Devil. The prayer that Agnes Sampson used to heal her patients was a version of "The Apostle's Creed," which she claimed she learned from her father:

\section{AGNES SAMPSON'S Prayer to her patients} for life or death.

I believe in Almighty God that created, both heaven and earth and all of the night, In to his dear son Christ Jesus, in to that without guile lord, I believe Was gotten of the Holy Ghost, born of the Virgin Mary, Taken to heaven, so that all will then, and sits at his father's right hand;

He bade us come, to the dwelling place both alive and dead, as he thought to assemble. I believe in the Holy Ghost, in Holy Church my hope is made, That holy-ship where holymen win, to ask forgiveness of my sins. And sign to rise in flesh and blood, the life that never more has gone.

Thou says, Lord, "loved might thee be, that formed and made mankind of me."

Thou cast me on the holy cross, and lent me body, full and voice, And ordained me to heaven's beliefs; wherefore I thank the lord of these; And all your holy men loved be, to pray to them to pray for me. And keep me from that fallen state, and from the sin that would slay, Thou, Lord, for they better passion in, to keep me from sin

And endless damnation. Grant me that joy never will be gone. Sweet Jesus Christ. Amen.122

Agnes Sampson was a popular woman with the people around Edinburgh. The only safe way to convict her of 
witchcraft against James was to convince those people that she had used the power of the Devil to effect her cures. By convincing them that she cured through prayer, foreknowledge, and miraculous power that could only be gained through the Devil, they could then convince those people that she could and did harm the king. Many of her clients came forward to accuse her of having the fore-knowledge that a sick person would recover or die. Historically, witnesses were extorted or brutalized into giving evidence, ${ }^{123}$ so some of them may not have been willing witnesses. Agnes was, also, accused of the fore-knowledge that a great rain would fall on the sea and the land and that the Queen would never reach Scotland unless the King went to fetch her.124 It was necessary to convince people that Agnes was seen by witnesses being visited by the Devil. The authorities could then accuse her of joining the Devil at the North Berwick Church to harm the King. ${ }^{125}$ By destroying her character, they could then convince the people that Agnes Sampson was a witch who called the Devil her master. She could abuse the simple people leading them to believe in the support of the Devil. Agnes was no longer the Wise Woman of Keith, but a "common sorcerer."126

Besides Gelie Duncan, Agnes Sampson was the only one of the principal accused that was not directly connected with the Earl of Bothwe1l. She was arrested because of the accusations of Gelie Duncan. She lived near Edinburgh and 
was famous. She was a widow and poor. She was Catholic in a severely Protestant country. She was a natural target of the witch-hunt. Indirectly, she was linked to Bothwell through Barbara Napier and Eufame MacCalzean. Both of them used her services as a midwife and both of them were openly good friends and supporters of the Earl of Bothwell.

The dittays against Barbara Napier were not as numerous or damning as those against John Cunningham and Agnes Sampson. Barbara Napier was acquitted of the charges of consulting with Agnes Sampson in the murder of her husband, the Edinburgh burgess Archibald Douglas. Douglas was the brother of Lord Carschogill and wealthy in his own right. He was a powerful merchant. He became ill, and the physician could not find a cause or a cure. This was a common occurrence in scotland at that time and was generally ascribed to witchcraft. Barbara Napier was also acquitted of asking Ritchie Graham, another of the North Berwick witches, to help her son and of asking him if the king would return from Denmark. She was acquitted of attending the North Berwick convention where James' death was planned and the storms were raised. She was convicted, however, of consulting Agnes Sampson for help in alleviating the morning sickness of her friend, Dame Jeane Lyons, Lady Angus. She was acquitted of seeking the death of Lord Angus in 1588, who languished from a disease that the doctor could not recognize and so assumed it was caused by witchcraft. ${ }^{127}$ 
Pitcairn notes that Lady Angus was never indicted for consulting with Barbara Napier and Agnes Sampson, even though her great-grandmother was a famous executed witch, Lady Glammis. Barbara Napier was acquitted on May 8, 1591. On May 10, James sent a letter to the Assize jurors demanding her execution. He stated that since she was convicted of consulting with Agnes Sampson, she was guilty of breaking the law of the Witchcraft Act of 1563 and should be burned at the stake. All her goods should then be forfeit to the king. Larner claims that the jury was reluctant to convict her because the clause imposing the death penalty for consulting a witch had never before been enforced. A month later, James retaliated by throwing the jury in prison. Meanwhile, Barbara Napier had been released when she proved she was pregnant to await the birth of her child.128 The editor of James' letters stated that she was left to the king's pleasure. Pitcairn and Larner speculated that she was never executed, yet James stated in a letter to John Maitland "Try, by the mediciners' oaths, if Barbara Napier be with bairn or not. Take no delaying answer. If ye find she be not, to the fire with her presently and cause bowel [disembowel] her publicly."129

James accused her jury of an "assize of error" and did not let them out of prison until they convicted her of witchcraft and treason. The jury had acquitted her because the evidence against her came from other accused persons 
under torture. James must have received criticism for his actions because he wrote and published an explanation of his interference called "The Tolbooth Speech." He stated: "By the Civil law I know that such persons are not received as witnesses, but in the matters of heresy [and] matters of witchcraft there is good reason that they be admitted. First none honest can know these matters, second, because they will not accuse themselves, thirdly, because no act that is done by them can be seen."130 Most historians accept that Barbara Napier was never burned for her involvement in the North Berwick trials because there was no record of the execution. I suspect that Barbara Napier was burned after the birth of her child because James was still involved in the aftermath of the trials in December 1592, when he prosecuted all the lairds for their involvement with, and support of, Bothwell. He wrote Maitland to burn her and disembowel her in public. Maitland, considering his hatred of Bothwell and Barbara's friendship for the Earl, would not have ignored James' demands. Considering the state of the economy at that time, which was badly hurting from the wedding trip and entertaining the Queen's brother after their return, James would not have given up the forfeiture of Barbara Napier's property or her execution since he was still angry a year later and still involved in the trials. 
In 1591, there were more than twenty trials dealing with the lairds and their relations who supported Bothwell. Most of those lairds or their relations were fined heavily, were banished with their movable goods and lands forfeited to the crown, and those in government positions lost their jobs and pensions. ${ }^{131}$ In addition to the trials of the lairds, two years later on May 4, 1592, Dame Margaret Douglas, the Countess of Bothwell, was put on trial for treason and for aiding her husband. She was convicted and all movable goods and lands were forfeit to the crown.132 Niniane Chirnesyde's trial for treasonably conspiring the death of the king by witchcraft, sorcery, and other traitorous and diabolical means' was held on May 28, 1591.133 Then, on June 9, two days after throwing the jury in prison, James made his famous "Tolbooth Speech." He went to the Tolbooth in Edinburgh where the trials were being held, and spoke "of his own impartialty, the use of witchcraft, the enormity of the crime . . the ignorance of thinking such matters mere fantasies, the cause of his own interference in the matter, the ignorance of the assize, the late trial, his own opinion of what witches really are."134 James was angry because, as far as he was concerned, Barbara Napier had tried to kill him and the jury acquitted her. He considered himself their father and he had written them a letter demanding her death. ${ }^{135}$ 


$$
\text { According to James, on All Hallow's Eve, 1589, a }
$$
convention of witches was held at the church at North Berwick to raise storms to prevent James and Anne from sailing to Scotland in May, 1590. Agnes Sampson proposed the death of the king and made a picture of wax in his likeness. The picture was promised to her by the Devil, but not delivered, so she finally made a wax representation herself. She gave the picture to Eufame MacCalzean and Barbara Napier at the next meeting. They were to roast it. They were supposed to receive some of the king:s linen to use in their enchantments, but did not. They next met at Barbara Napier's house to make their plans for the next convention at North Berwick Church. They met on All Hallow's Eve, 1590. A black man appeared with a black book in his hand. He was the Devil. He did not have the wax picture of James that he had promised, but would later give it to Barbara Napier and Eufame MacCalzean. ${ }^{136}$ James also accused them of robbing graves in the churchyard, dancing (which was strictly forbidden by the Kirk) and kissing the Devil's arse. Twice in his speech, James accused Barbara Napier of being at the Brig 0 ' Dee Bridge when James defeated and arrested Huntly. That was where she consulted Richard Graham about the Earl of Bothwell's approaching the city while James was there. By tying Barbara Napier's name with Bothwell and the Brig $0^{\prime}$ Dee, he connected her with the Brig $0^{\prime}$ Dee conspiracy. None of this appeared in Barbara 
Napier's dittays, and this is the first mention of the Earl of Bothwell's name in the trials.

Barbara Napier's trial was significantly different from the trials of John Cunningham and Agnes Sampson. There was no mention of the Devil's pact, demonology or the Devil's mark. There is also no mention in any of the literature of Barbara Napier being tortured. Barbara Napier was put on trial because she was Bothwell's friend. She was wealthy and she was Catholic. Her trial set a precedent in Scotland. The wealthy upper classes were never tortured to elicit testimony or evidence and, generally, they were not executed for witchcraft. If executed, the crime was usually treason. To this point in Scottish history, Barbara Napier's trial was traditional. Then James interfered. The dittay listed against the jurors who were jailed at James' insistence reads similar to the tract Newes from Scotland. There is no longer a sense of dignity in the proceedings, but fantasy and fear. The king of scotland publicly admitted that the testimony of unreliable people elicited under torture could be admitted as evidence in a trial. The trial of Barbara Napier's jury paved the way for Eufame MacCalzean's trial and for the Earl of Bothwell's destruction.

On June 9 th, Eufame MacCalzean was brought to trial after being tortured. James demanded that she "see the stoup two or three days and upon the sudden stay hex in hope 
of confession if that service adverts. If not, despatch her the next oulke anis [next week sometime] but not according to the rigour of the doom."137 The testimony against her was similar to that brought against Barbara Napier. She was accused of consulting with various witches for help with childbirth. She was accused of trying to kill her husband while he was in France and she was in Scotland, first with the pox and then in an unknown way. This time the jury convicted. She was convicted of attending the convention at North Berwick and planning the destruction of the king with storms.138 Eufame MacCalzean was sentenced on June 11 to be taken to Castle Hill in Edinburgh, bound to a stake, and "burnt in affis, quick, to the death." "Quick" meant that she was to be burnt alive and not strangled first. She was the first person to die in this manner in Scotland. Pitcairn stated that this was the severest sentence ever pronounced by the Court. Eufame MacCalzean "endured her fate with firmness and obstinacy to the last." she did not repent her crimes. ${ }^{139}$ Sometime between the letter to Maitland and Eufame MacCalzean's trial, James changed his mind about her sentence. He had originally instructed Maitland to torture her and then dispatch her, but not to the rigors of the Act of 1563.140

Eufame MacCalzean was the daughter of Lord Cliftonhall, a judge and Senator of the Estates of Parliament. She was educated, which was uniusual for wornen at that time. Some 
women could read, but few could write their names. Eufame was given an education by her father and was well read. In 1578, Lord Cliftonhall made her executrix and assignee of his estates. Her husband John Moscrop, advocate, took her family name when they married in compliance with the entail of the estate. When Eufame MacCalzean was convicted of treason and witchcraft, her estates were forfeited to the king who gave them to his favorite Sir James Sandelandis. Her other possessions and income James kept.

Eufame MacCalzean was an outspoken friend to the Earl of Bothwell. Pitcairn stated that she was openly Catholic and hated the king for his Protestantism. She may have been involved in the Brig $O^{\prime}$ Dee Conspiracy but, so far, no proof has been found of her involvement. She was burned on June 26, 1591. Three days earlier, the Earl of Bothwell escaped from Edinburgh Castle where he had voluntarily incarcerated himself. James issued a decree of forfeiture against him. 1.41.

James Melville stated that both Barbara Napier and Eufame MacCalzean were known as civil honest women before they were arrested. Eufame MacCalzean was unhappily married. She was known for her sharp wit and tongue, and for being strong minded. ${ }^{142}$ According to the Calendar of Scotland, 1589-1593, she "dyed very obstynatly without confessing any cryme."143 Her connection with the North Berwick trials started in the same way as Barbara Napier's. 
She consulted Agnes Sampson for help in childbirth. She had lost babies at birth and went to Agnes Sampson for a charm to ensure the safe delivery of her children. Her next two children were born alive and survived childhood.

James hated Eufame MacCalzean because she had ridiculed his fear in public. His revenge, aside from burning her alive, was to wipe out her family name.144 Both Barbara Napier and Eufame MacCalzean, like John Cunningham, were destroyed because of their friendship with Francis stewart Hepburn, the fifth Earl of Bothwell.

In November 1589, the Earl of Bothwell was up on the stool of repentance in the High Kirk of St. Giles and Robert Bruce, minister, preached a sermon at him. The pre-1590 attitude of the clergy toward the Devil focused on the actions instigated by the Devil's influence not the physical worship of Satan himself. ${ }^{145}$ There was no suggestion by Bruce, or any others, that Bothwell was a sorcerer or even consulted with sorcerers. Bothwell was a notorious rake constantly in trouble for his raucous activities and always asking forgiveness from the Kirk and James, and receiving it. James adored Bothwell the way any young man would adore a dashing, handsome laird. Bothwell was everything that James was not, the epitome of the romantic scottish laird. Before the 1590 trials began, Bothwell was one of James' most trusted supporters. When James left to collect Anne, he left Bothwell, the Chief Admiral, in charge of the 
country. Perhaps it was on this trip that Maitland began to see a way to dispose of his enemy. Given James' sudden interest in witchcraft that year, with his visits to Mary MacIngarruch of the Hector Munro trial, and the current trials in Edinburgh and Aberdeen, he would have been very interested in Admiral Peter Munk's suspicions and accusations.

When James visited Tycho Brahe and Niels Hemmingsen and discussed demonology with Lutheran intellectuals and clergy, Maitland could have laid the foundations of his plan. We know that Maitland was with James at Tycho Brahe's home because he wrote poetry there to prove he, like James, was a scholar. ${ }^{146}$ That Maitland was behind the plot to destroy the Earl was generally accepted by Bothwell, the nobility and the common people. By December 1591, Bothwell was raiding Holyrood House trying to get to James and to capture Maitland. Maitland was his main target.

Bothwell was following the pattern of Scottish history, that the physical presence of the King was the assurance of power. The Scottish lairds were always direct in their actions. If Bothwell had meant to harm James he would have done so. The support of the people and the gentry was with Bothwell, not the king and Maitland. When the people rushed to the king's defense and ran Bothwell off, they stated uncategorically that they did it because James was the "king" not because they believed him or liked him. 
Historical precedent was for Bothwell to stick a knife in James and proclaim himself king. He did not do so. He proclaimed his love and support for James and demanded Maitland clear him of the witchcraft charges. James promised to do so.

Why James changed his mind is unclear, but Maitland was left in the castle with him while Bothwell was again on the run. Perhaps he used jealousy and fear as the convincing argument. While James was ugly, Bothwell was handsome. While James was bumptious, Bothwell was dashing and romantic. The Queen admired Bothwell and spent hours conversing with him in French. Bothwell must have been a great threat to James, who considered himself God's chosen on Earth. Bothwell was popular with the people, while James was detested by them because he was openly contemptuous of those same people. The people were not the only ones who supported Bothwell. The lairds that James sent out to capture him, joined him. Bothwell was a killer and James feared death. Earlier in Edinburgh, Bothwell had stabbed William Stewart of Monkton in the lungs. His men finished Stewart off in the cellar. James knew this. ${ }^{147}$ He would have rested easier knowing that Bothwell was destroyed. The fall of the Earl of Bothwell began in January 1591, when he helped John Cunningham escape from the Tolbooth in Edinburgh. The Earl also kidnapped one of the witnesses against Cunningham and threatened to hang him if he did not 
change his testimony. ${ }^{148}$ James rode out that night to find Bothwell in Kelso. If James believed that Bothwell was the "Black Man" of Agnes Sampson's testimony, why would he ride out to meet him? Bothwell was not under arrest, therefore, his power as a witch would not be neutralized and his witchcraft could have harmed James. James warned Bothwell that night to mend his ways or the law would be enforced against him.149 This was before Barbara Napier's trial when Bothwell's name became prominent as a witchcraft suspect. In April, he was summoned before the Privy Council, where he was accused of leading witches in the raising of storms to harm Anne and James. He denied the charge and was incarcerated in Edinburgh Castle. In June, after Eufame MacCalzean's trial, he escaped. By July, he was declared an outlaw. Three days later he threw a forty-shilling piece on the causeway and defied the Chancellor to catch him. In December, driven by desperation, Bothwell entered Holyrood House and demanded Maitland be handed over to him.150 Bothwell not only did not find Maitland, but he terrified James and lost all credibility with the king.

Scotland was still a feudal society as far as the lairds were concerned. Bothwell was a laird who loved the old ways. The scottish lairds thrived on conspiracy and betrayal. James had loved Bothwell for the same qualities that he eventually came to loath and fear. James was desperately afraid and he was ruthless enough to destroy 
hundreds of lives to protect himself and destroy the power of the lairds. After Bothwell's escape to Italy, Huntly, who was still involved in returning scotland to Roman Catholicism, also became an exile. James had triumphed over his rivals, and, in the process, imposed demonological theory on Scottish witchcraft trials. 
Chapter six

\section{CONCIUSION}

With the subject matter of this paper, I have tried to show the background and the reasons that James VI, an erudite genius, could believe that there was a satanic conspiracy against him, could use his unique power as king to control his enemies, his family, and his people by starting and directing the North Berwick witchcraft trials. The first twenty years of James' life were truly tragic. He was raised in a home without love, with the specter of his father's murder, his mother's imprisonment, frequent assassinations and deaths, and his own kidnappings. Those he loved did not live long. He was a pawn for those currently in power. His body was misshapen, yet he had the mind of a genius. He loved to learn and to disseminate his learning to others. He was forced into a marriage he did not want. James was terrified of being assassinated. The storms that prevented Anne's reaching Scotland and assailed his own trip terrified him. Initiating the witch-hunt of 1590 and discovering the North Berwick plot was his way of taking power over events he could not otherwise control. Connecting the witches with his rival for the throne, the 
Earl of Bothwell, helped him consolidate his position and begin the downfall of the lairds as the ruling power in Scotland. The attack on his person by the Devil proved that he was, indeed, God's viceroy.

When James went to Denmark in 1589 , he was full of high hopes for love and companionship from his beautiful, fifteen-year-old-bride, Anne. He soon realized that not only was Anne not intellectual, but that she had no interest in erudite conversations and considered him boring. ${ }^{151}$ James' views on women were representative of his time. They were enhanced by his interest in the Greek authors who were openly homosexual, believing that the greatest love was that between men. Women were necessary for breeding and were kept in seclusion. James was openly homosexual and continuously had affairs with handsome young men whom he favored with gifts and titles.

There is little known of Scottish women in the sixteenth century. Most of what we know comes from comments in trial records, diaries, and letters. Scottish women were described as bold, honest, courteous, graceful, handsome, and were the absolute mistresses of their husbands and their homes.152 They had no rights under the law, though, and the only crimes they could be tried for were adultery, murder, treason, infanticide, and witchcraft. A woman could not stand pledge in a court of law, and her nearest male relative pledged his appearance and stood for fines.153 So, 
witchcraft became a "crimen exceptem," exempt from amnesty and any movable goods of the accused were forfeited to the crown and could not be returned. ${ }^{154}$ When a woman was accused of witchcraft she was doomed because no lawyer would represent her and no witnesses would come forward to speak in her behalf. If any one took her side, he or she would then be accused of witchcraft. ${ }^{155}$ only a witch would defend a witch, as James stated in his "Tolbooth Speech." So, when Gelie Duncan was tortured to prove she was a witch, the fate of those she accused was irrevocable. Because women were barred from appearing as witnesses at trials, a special act was passed in 1591 to allow their testimony in the North Berwick trials and those that followed. ${ }^{156}$ James was willing to change the law to get what he wanted.

In the Daemonologie, in Forme of a Dialogue, which James wrote in 1591, he tried to validate his involvement in the North Berwick trials. The Scottish people were very outspoken and James did not have their open support during the trials and the subsequent pursuit of Bothwell. He also needed to explain his actions to the English and Queen Elizabeth. In the Daemonologie, he explained that witches lost their powers when arrested if the magistrate was "diligent in examining them" and God would protect him because the witches' "power is then no greater than before that ever they meddled with these their master."157 James decided that only the extreme pain of torture could free the 
witch from the Devilis8 and that God would not permit that any innocent person would be accused. ${ }^{159}$ James stated that witches could cause death by burning a picture or using a wax figure, and could raise storms at sea. He alleged that more women were witches than men because that is "where the Deuill findes greatest ingnorance and barbaritie."160 James substantiated his use of the confessions by torture of Gelie Duncan, Agnes Sampson, and John Cunningham to try Barbara Napier, Eufame MacCalzean, and the Earl of Bothwell by stating in the Daemonologie that only "witches" can be proof, and so witnesses to the doing of witches."161 He answered the criticism and shock of his people at Eufame MacCalzean's and Barbara Napier's trials and executions by stating "the consulters and entertainers of these craft folk [wise women] are equally guilty with them that are the praticers."162 In the manuscript of the Daemonologie that Rhodes Dunlap found in the Folger Shakespeare Library, James VI had written initials in the margins. He wrote "EM" by the statement "riche and worldlie wyse" and "BN" was written by the statement "geuin over to the pleasours of the flesche." "EM" was Eufame MacCalzean and "BN" was Barbara Napier. ${ }^{163}$

The prosecution figures of the North Berwick witches are contradictory in several sources. Some list thirty-nine on trial, ${ }^{164}$ but Christina Larner listed seventy records in her A Source-book of Scottish Witchcraft and claimed that 
hundreds were accused with fate unknown. ${ }^{165}$ The court records are incomplete for that period and some of the listings are just "certain witches," "familiars of," "several people," or the entries are left blank.166 of the sixty-five names that Larner lists, fifty-one were women; however, it is generally accepted that more than two hundred persons were accused in the North Berwick trials. Two hundred seems a low figure by today's standards, but Scotland had a probable total population of less than 800,000 in the latter part of the sixteenth century, so the importance of these trials was considerable. Furthermore, the personal intervention of James VI and his introduction of demonological theory into scottish law provided a special impetus to the further persecution of witches in Scotland, and with the publication of the Daemonologie in 1597, James started Scotland's second great witch-hunt. 


\section{ENDNOTES}

${ }^{1}$ An esbat is a meeting attended by a small group of witches, whereas a sabbat is a meeting attended by a large group of witches.

${ }^{2}$ Edgar Peel and Pat Southern, The Trials of the Lancashire witches: a study of seventeenth-Century Witchcraft (New York: Taplinger Publishing Company, 1969), 33 .

${ }^{3}$ Ronald Seth, Witches and Their Craft (New York: Taplinger Publishing Company, 1967), 67

${ }^{4}$ Selma R. Williams and Pamela J. Williams, Riding the Night Mare: Women and Witchcraft (New York: Antheneum, 1978), 84 .

${ }^{5}$ Selma Williams, 65-66.

"Jeffrey Burton Russell, A History of Witchcraft: Sorcerers, Heretics and Pagans (London: Thames \& Hudson, 1980), 40-42.

${ }^{7}$ I include Antonia Fraser among the feminists for her later books on women's history: The Warrior Queens (New York: Alfred A. Knopf, 1989) and The Weaker Vessel (New York: Alfred A. Knopf, 1984).

${ }^{8}$ Christina Larner, Witchcraft and Religion: Politics of Popular Belief (Oxford: Basil Blackwell, 1984), 87 .

${ }^{9}$ Hugh V. McLachlan and J.K. Swales, "Stereotypes and Scottish Witchcraft," Contemporary Review 234 (February 1979): 88 .

${ }^{10}$ Christina Larner, Christopher Hyde Lee, and Hugh V. McLachlan, A Source-Book of Scottish Witchcraft (Glasgow: University of Glasgow, 1977), 120 .

${ }^{11}$ Larner, Witchcraft, 87.

${ }^{12}$ G.R. Quaife, Godly Zeal and Furious Rage: The Witch in Early Modern Europe (New York: St. Martin's Press, 1987), 132 .

$$
{ }^{13} \text { Quaife, } 88 \text {. }
$$


${ }^{14}$ Selma Williams, 15-16.

${ }^{15}$ Nancy Van Vuuren, in The Subversion of Women: as Practiced by Churches, Witch-hunters, and Other Sexists (Philadelphia: Westminster Press, 1973), states that Malleus Maleficarum, known as "The Hammer of Witches, a bible for judges, was published in 1486 and written by Heinrich Kramer and Jacob Sprenger. These inquisitors, appointed by Pope Innocent VIII in 1484 to wipe out

witchcraft in northern Germany, stated that witchcraft was a woman's crime. Selma R. Williams and Paula A. Williams state that there were fourteen editions between 1487 and 1520 and sixteen more between 1574 and 1669 . It is known that two copies were sold at oxford as early as 1520 , and that English intellectuals had read the book long before its British printing.

${ }^{16}$ The Inquisitorial Process originated with the Romans and was adapted to the Church's needs which was to eradicate heresy. The Inquisition took its name from the process. The process was totally weighted to the benefit of the Inquisitor. The finalized process: (1) the lawyer's function, if the accused was allowed one, was to convince her to confess, (2) the trial was secret, requiring a confession obtained under torture, (3) if the accused maintained her innocence, she could be imprisoned for life, (4) the accused had to confirm her confession three days after the original confession to prove she was using free will and not confessing because of torture, (5) if she confirmed the confession she was given penance or punishment, but (6) if she withdrew the confession, she was burned as an unrepentant heretic. Norman Cohn, Europe's Inner Demons: An Enquiry Inspired by the Great Witch-Hunt (London: Heinemann Educational Books, 1975), 24 .

${ }^{17}$ Brian P. Levack, The Witch-Hunt in Early Modern Europe (London: Longman Group, 1987), 183.

${ }^{18}$ Geoffrey Scarre, Witchcraft and Magic in $16 \mathrm{th}$ and 17the Century Europe (Atlantic Highlands, New Jersey: Humanities Press International, Inc., 1988), 17.

${ }^{19}$ Selma Williams, 109.

${ }^{20}$ Antonia Pakenham Fraser, King James VI of Scotland, I of England (New York: Alfred A. Knopf, 1975), 69.

${ }^{21}$ E.S. Turner, May It Please Your Lordship (London: Michael Joseph, 1971), 46 .

$$
22 \text { Fraser, 29-30. }
$$




$$
{ }^{23} \text { Ibid. , 33-34. }
$$

${ }^{24}$ Alan G.R. Smith, The Reign of James VI and I (New

York: St. Martin's Press, 1973), 6 .

25 John Graham Dalyell, The Darker Superstitions of Scotland (Norwood, Pennsylvania: Norwood Editions, 1973), 200 .

${ }^{26}$ Ibid., 132 .

${ }^{27}$ Charles Kirkpatrick Sharpe, A Historical Account of the Belief in Witchcraft in Scotland (Detroit, Michigan: Gale Research Company, 1974), 30 .

${ }^{28}$ Ibid., 38.

29 Fraser, 30 .

30John Prebble, The Lion in the North, (Middlesex, England: Penguin Books, 1973), 216 .

${ }^{31}$ Fraser, 26-28.

${ }^{32}$ Plantagenet Fry and Fiona Somerset Fry, The History of Scotland (London: Routledge and Kegan Paul, 1982), 157.

${ }^{33}$ G.P.V. Akrigg, Letters of King James VI and I (Berkeley: University of California Press, 1984), 5.

34 J.D. Mackie, A History of Scotland, new and rev. ed. (New York: Dorset Press, 1985), 169-70.

${ }^{35}$ David Harris Willson, King James VI and I (New York: Oxford University Press, 1967), 44 .

${ }^{36}$ Ibid., 22 .

${ }^{37}$ Ibid., 26.

${ }^{38}$ Fraser, $32-33$.

${ }^{39}$ M.I. Clarke, "The Education of a Prince in the Sixteenth Century: Edward VI and James VI and I," History of Education 7, no.1 (1978): 18 .

${ }^{40}$ Stewart is the Scot's spelling of the family name. The first member of the family to use the name was Robert the steward, who was proud of his connection with the royal family. His line became royal when he married Robert the Bruce's daughter, Marjory. Stuart is the French spelling of 
the same name. James adopted the French spelling when he went to England. Wallace Notestein, The Scot in History: A Study of the Interplay of Character and History (New Haven: Yale University Press, 1947), 20.

41 Gordon Donaldson, Scotland: James V to James VII (New York: Frederick A. Fraeger, Publishers, 1966), 57.

${ }^{42}$ Wallace Notestein, The Scot in History: A Study of the Interplay of Character and History (New Haven: Yale University Press, 1947), 68 .

43 Jenny Wormald, Court, Kirk, and Community: Scotland 1470-1625 (Toronto: University of Toronto Press, 1981), 14.

${ }^{44}$ C.M. Matthews, English Surnames (New York: Charles Scribner's Sons, 1967), 73 .

${ }^{45}$ Robert Fox, Kinship and Marriage: An Anthropological Perspective (Middlesex, England: Penguin Books Ltd., 1971), 159 .

${ }^{46}$ Wormald, 14.

47 Ibid. , 181.

${ }^{48}$ Willson, $96-100$.

49 Ibid. , 99.

50 Ibid., 100.

${ }^{51}$ David Mathew, James I (London: Eyre and Spottiswoode, 1967), 57 .

${ }^{52}$ Willson, 79.

${ }^{53}$ The Borderers were lawless men who lived near the English border and raided that area

${ }^{54}$ Donaldson, 191.

55 Ibid.

56Jennifer M. Brown, "Scottish Politics 1567-1625," in Alan G.R. Smith, ed., The Reign of James VI and I (New York: St. Martin's Press, 1973), 22.

${ }^{57}$ Donaldson, 56-57.

${ }^{58}$ Clarke, 18. 


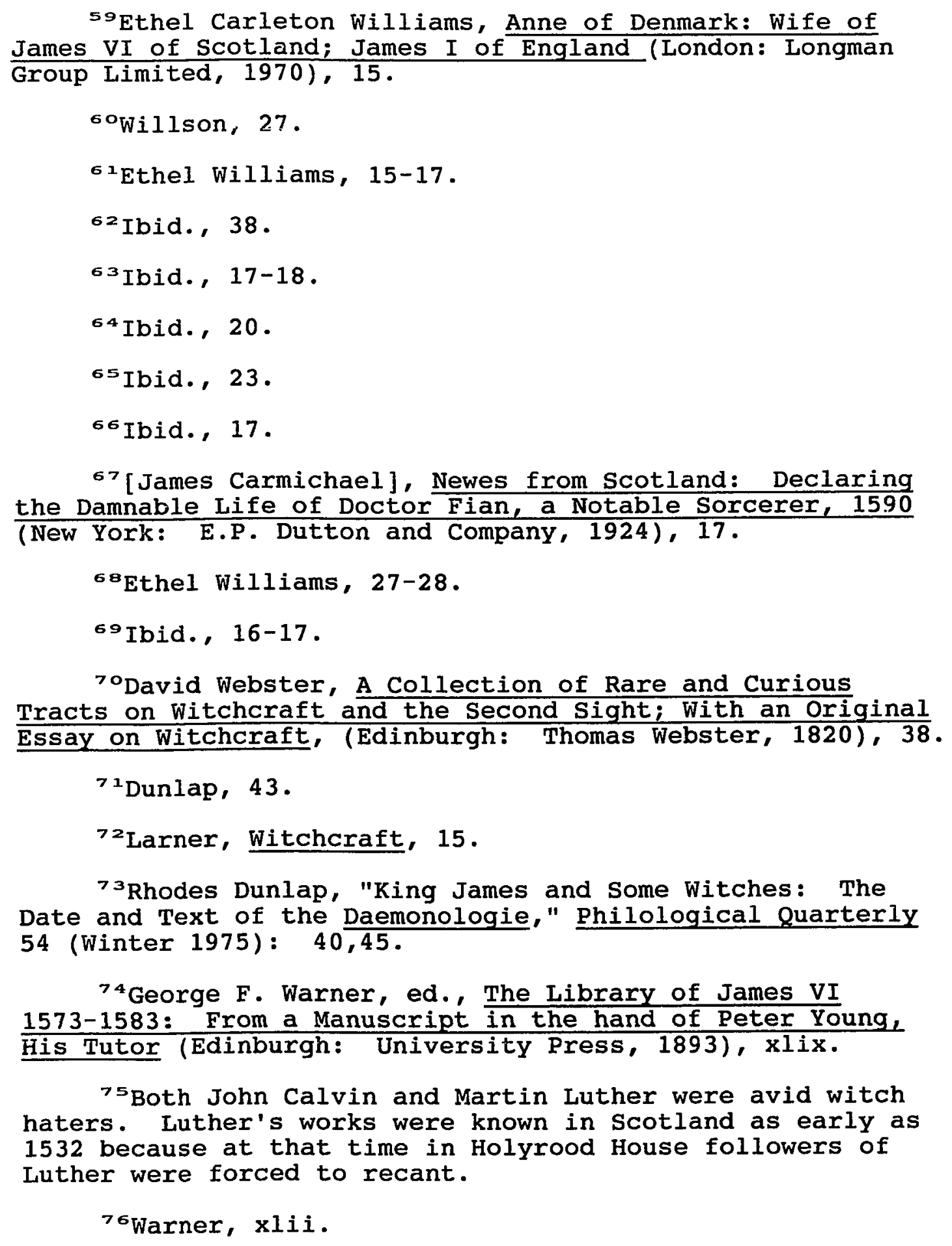


${ }^{77}$ Frances A. Yates, The Occult Philosophy in the Elizabethan Age (London: Routledge and Kegan Paul, 1979), 70 .

${ }^{78}$ Ibid., 91.

${ }^{79}$ Dunlap, 41.

${ }^{80}$ Robert Pitcairn, Criminal Trials in Scotland from A.D. 1488 to A.D. 1624 . . Compiled from the Original Records and MSS, Vol. I (Edinburgh: 1833), 21-22.

${ }^{81}$ Larner, Source-book, 4-5.

${ }^{82}$ Dalyell, 251.

${ }^{83}$ Ibid., 249.

6.7.L. Simons, l'he Witchcraft World (ivew York: Barries and Noble, 1974), 113 .

85 [Carmichael], 18.

${ }^{86}$ Selma Williams, 96-97.

${ }^{87}$ Pelliwinks were fitted over the fingers and turned to crush them. In winching, the victim's head was tied and thrown about.

${ }^{88}$ The Devil's mark was placed by Satan on the victim to seal their bargain and was usually found in the vagina.

${ }^{89}$ Shulamith Shahar, The Fourth Estate: A History of Women in the Middle Ages (London: Methuen, 1983), 20 .

$9{ }^{\circ}$ Donaldson, 46 .

91I.D. Whyte, "Population Mobility in Early Modern Scotland," in R.A. Houston and I.D. Whyte, Scottish Society 1500-1800 (Cambridge: Cambridge University Press, 1989), 39 .

${ }^{92}$ Whyte, 58.

${ }^{93}$ R.A. Houston, "Women in the Economy and Society of Scotland, 1500-1800," in R.A. Houston and I.D. Whyte, Scottish Society 1500-1800 (Cambridge: Cambridge University Press, 1989), 136 .

${ }^{94}$ Houston, 136 . 


$$
\begin{aligned}
& 95 \text { Levack, } 26 . \\
& { }^{96} \text { Helen Stafford, in her essay "Notes on Scottish }
\end{aligned}
$$
Witchcraft Cases, 1590-91" in Norton Downs, ed., Essays in Honor of Conyers Read (Chicago: University of Chicago Press, 1953), states that David Seaton was well rewarded by James for his activities in instigating the North Berwick trials. The English ambassador to Edinburgh wrote to Lord Burghley, his superior that Seaton was sent to Fngland to "seek out those witches who had fled" scotland.

97George F. Black, A Calendar of Cases of Witchcraft in Scotland 1510-1727 (New York: Arno Press, Inc., 1971), 24.

${ }^{98}$ Ronald Holmes, Witchcraft in British History (London: Frederick Muller Limited, 1974), 108 .

${ }^{99}$ Selma Williams, 96-7.

10opitcairn, 219 .

${ }^{101}$ Notestein, 96.

${ }^{102}$ Pitcairn, 219.

${ }^{103} \mathrm{His}$ feet were placed in a vise enclosing the legs from the ankles to the knees and operated by screws or wedges. As the screws were tightened, the legs would be lacerated and crushed. Rossell Hope Robbins, Encyclopedia of Witchcraft and Demonology (New York: Crown, 1959).

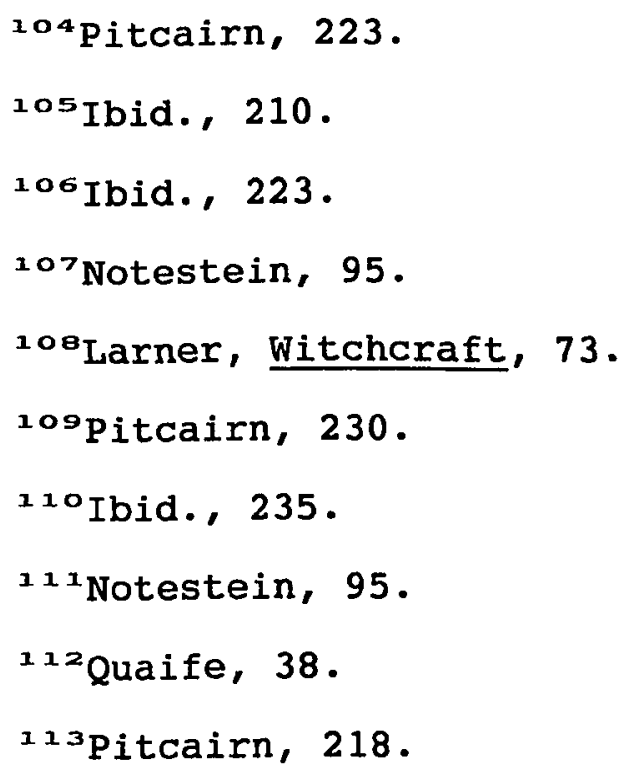


114 Ibid. , 230.

115 Ibid. , 231.

116 Ibid. , 241.

${ }^{17}$ Cunning-folk, wise women, healers, and witches were all synonymous terms.

${ }^{118}$ Keith Thomas, Religion and the Decline of Magic (New York: Charles Scribner's Sons, 1971), 206.

119 Ibid. , 85.

120 Ibid. , 264.

${ }^{121}$ Keith Thomas, "The Relevance of Social Anthropology to the Historical Study of English Witchcraft" in Mary Douglas, ed., Witchcraft Confessions and Accusations

(London: Tavistock Publications, 1970), 57 .

122 Pitcairn, 234 .

${ }^{123}$ Quaife, 58 .

${ }^{124}$ Pitcairn, 232.

125 Ibid. , 235-36 .

126 Ibid., 241.

127 [Carmichael], 11.

${ }^{128}$ Pitcairn, 242-44.

129 Akrigg, 114 .

130 Peel, 33-34

${ }^{131}$ Pitcairn, 257-67.

132 Ibid. , 267-74 .

$13{ }^{3} \mathrm{Black}, 24$.

${ }^{34}$ Notestein, 96 .

${ }^{135}$ Christina Larner, "James VI and I and Witchcraft," in Alan G.R. Smith, The Reign of James VI and I (New York: St. Martin's Press, 1973), 83 . 


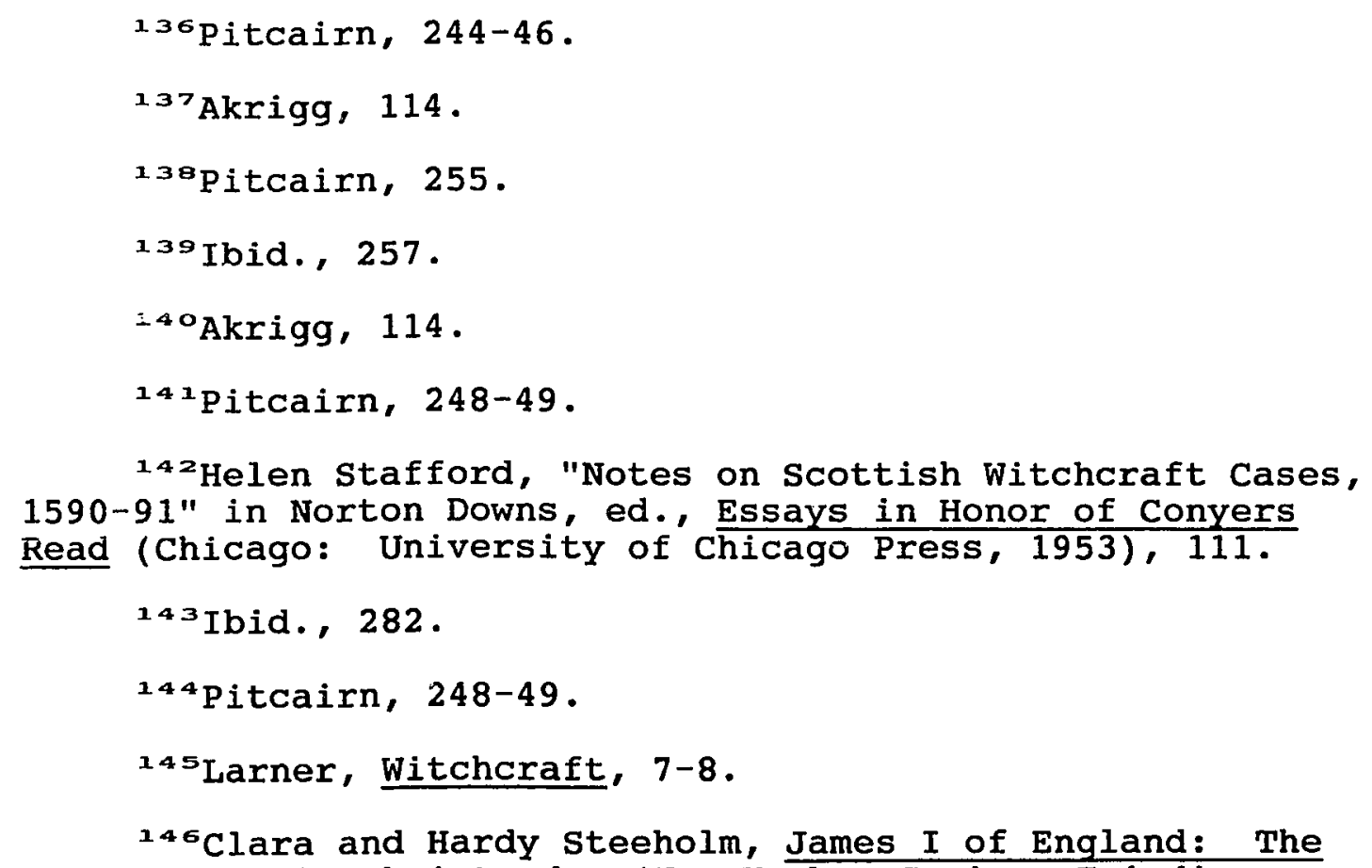
him. The handsome Earl of Keith had gone through the proxy ceremony with her and James was anything but handsome. He was middle height, broad shouldered, with bent legs from childhood rickets. One foot was permanently turned outward. He is described as being tadpole shaped because his fear of assassination caused him to wear multi-layers of clothes. An abnormally small jaw made his tongue too big for his mouth causing him to spill and dribble food and drink when he ate.

$$
\begin{aligned}
& 152 \text { Prebble, } 153 . \\
& 153 \text { Shahar, } 244 .
\end{aligned}
$$


${ }^{154}$ Christina Larner, Enemies of God: The Witch-Hunt in Scotland, (Baltimore, Maryland: The Johns Hopkins University Press, 1981), 68 .

${ }^{155}$ Quaife, 25 .

156 Joseph Klaits, Servants of Satan: The Age of the Witch Hunts (Bloomington, Illinois: Indiana University Press, 1985), 70 .

157 James VI. The Daemonologie, in Forme of an

Dialogue, (New York: E.P. Dutton and Company, 1924), 50 .

${ }^{158}$ Larner, Enemies, 70 .

159 Scarre, 59.

160 James VI, 69 .

${ }^{161}$ Peel, 57.

162 Ibid. , 128 .

163 Dunlap, 40 .

${ }^{164} \mathrm{Willi}$ am Woods, A Casebook of Witchcraft: Reports, Depositions, Confessions, Trials, and Executions for Witchcraft During a Period of Three Hundred Years (New York: G.P. Putnam's Sons, 1974), 96-98.

${ }^{165}$ Larner, Witchcraft, 69.

${ }^{166}$ Larner, Source-book, 194, 3, 192 . 


\section{SEIECTED BIBIIOGRAPHY}

Achterberg, Jeanne. Woman as Healer. Boston: Shambhala, 1990 .

Adam, Isabel. Witch Hunt. London: Macmillan London Limited, $1 \overline{978 .}$

Adler, Margot. Drawing Down the Moon. Boston: Beacon Press, 1979 .

Akrigg: G.P.V. Letters of King James VI and I. Berkeley: University of California Press, 1984 .

Anglo, Sydney, ed. The Damned Art: Essays in the Literature of witchcraft. London: Routeledge and Kegan Paul, 1977.

Baroja, Julio Caro. The World of the Witches, trans. O.N.V. Glendinning. Chicago: University of Chicago Press, 1965 .

Bingham, Caroline. The Stewart Kingdom of Scotland 1371-1603. London: Weidenfeld and Nicolson. 1974 .

Black, George R. A Calendar of Cases of Witchcraft in Scotland 1510-1727. New York: Arno Press, Inc., 1971.

- The Surnames of Scotland: Their Origin, Meaning, and History. New York: The New York Public Library, 1962 .

Black, William George. Folk Medicine: A Chapter in the History of Culture. New York: Burt Franklin, 1970.

Booth, Sally Smith. The Witches of Early America. New York: Hastings House, Publishers, 1975.

Boulding, Elise. The Underside of History. Boulder, Colorado: Westview Press, 1976.

Bridenthal, Renate and Claudia Koonz. Becoming Visible: Women in European History. Boston: Houghton Miffin Company, 1977. 
Briggs, K. M. Pale Hecate's Team. London: Routledge and Kegan Paul, 1962 .

Brodie-Innes, J.W. Scottish Witchcraft Trials. London: The Chiswick Press, 1841.

Brown, Jennifer M. "Scottish Politics 1567-1625," in Alan G.R. Smith, ed. The Reign of James VI and I. New York: St. Martin's Press, 1973: 22-39.

Bruce, Robert. Sermons in the Kirk of Edinburgh. London: Woodrow Society, 1843 .

Burton, John Hill. Narratives from Criminal Trials in Scotland, 2 Vols. New York: First AMS Press, Inc., 1976 .

- mise History of Scotland: From Agricola's Invasian to the Revolution of 1588, vol. Edinburgh: William Blackwood and Sons, 1870 .

Calvin, John. The Man and His Ethics. New York: Abingdon Press, 1931 .

Cameron, Joy. Prisons and Punishment in Scotland: From the Middle Ages to the Present. Edinburgh: Canongate, 1983 .

Carmody, Denise Lardner. The Oldest God: Archaic Religion Yesterday and Today. Nashville, Tennessee: Parthenon Press, 1981.

[Carmichael, James]. Newes from Scotland: Declaring the Damnable Life of Doctor Fian, 1590. Edinburgh: William Wright, 1924 .

Clarke, Garrett. "Women and Witches: Patterns of Analysis," Signs: Journal of Women in Culture and Society 3 (1977): 461-70.

Clarke, M.L. "The Education of a Prince in the Sixteenth Century: Edward VI and James VI and I" History of Education 7 (1978): 7-19.

Cohen, Albert $\mathrm{K}$. Deviance and Control. Englewood Cliffs, New York: Prentice-Hall, Inc., 1966.

Cohn, Norman. "The Myth of Satan and His Human Servants," in Mary Douglas, ed. Witchcraft Confessions and Accusations. London: Tavistock Publications, 1970 . 
Europe's Inner Demons: An Enquiry Inspired by the Great Witch-Hunt. London: Heinemann Educational Books, 1975 .

Cowan, Ian B. The Scottish Reformation: Church and Society in Sixteenth Century Scotland. New York: St, Martin's Press, 1982.

Daly, Mary. Gyn/Ecology: The Metaethics of Radical Feminism. Boston: Beacon Press, 1978 .

Dalyell, John Graham. The Darker Superstitions of Scotland. Norwood, Pennsylvania: Norwood Editions, 1973.

Daraul, Arkon. Witches and Sorcerers. London: Frederick Muller Limited, 1962 .

Davidson, Thomas. Rowan Tree and Red Thread. Edinburgh: Oliver and Boyd, 1949.

De Riencourt, Amaurey. Sex and Power in History. New York: David McKay Company, Inc., 1974.

Demos, John. "Underlying Themes in the Witchcraft of Seventeenth Century New England" The American Historical Review 75 (June 1970): 1311-26.

Donaldson, Gordon. "The Scottish Church 1567-1625" in Alan G. R. Smith, ed. The Reign of James VI and $I$. New York: St. Martin's Press, 1973: 40-56.

- Mary Queen of Scots. London: The English Universities Press Ltd., 1974.

- Scotland: James V to James VII. New York: Frederick A Praeger, Publishers, 1966.

Douglas, Mary, ed. Witchcraft Confessions and Accusations. London: Tavistock Publications, 1970 .

Douglas, Ronald MacDonald. Scottish Lore and Folklore: A Selection of Poetry, Rhymes, Tales, and Prose. New York; Bonanza Books, 1982 .

Dunlap, Rhodes. "King James and Some Witches. The Date and Text of the Daemonologie." Philological Quarterly 54 (Winter 1975): 40-46.

Dworken, Andrea. Woman Hating. New York: E. P. Dutton, 1974 . 
- Pornography: Men Possessing Women. New York:

E.P. Dutton, 1989 .

Ehrenreich, Barbara and Deirdre English. Witches, Midwives, and Nurses: A History of Women Healers. Old Westbury, New York: The Feminist Press, 1973.

Engelsman, Joan Chamberlain. The Feminine Dimension of the Divine. Philadelphia: The Westminster Press, 1979.

Forbes, Thomas. "Midwifery and Witchcraft." Journal of the History of Medicine (April 1962): 264-83.

Fox, Robert. Kinship and Marriage: An Anthropological Perspective. Middlesex, England: Penguin Books Ltd., 1971.

Fraser, Antonia. Mary Queeen of Scots. New York: Dell Publishing Company, Inc., 1969. 1989 .

The Warrior Queens. New York: Alfred A. Knopf, 1984

The Weaker Vessel. New York: Alfred A. Knopf,

Fraser, Antonia Pakenham. King James VI of Scotland, I of England. New York: Alfred A. Knopf, 1975.

Fry, Plantagenet and Fiona Somerset. The History of Scotland. London: Routledge \& Kegan Paul, 1982.

Gage, Mathilda Joselyn. Women, Church and State. Watertown, Massachusetts: Persephone Press, 1893.

Green, A.E. Witches and Witch-Hunters. Yorkshire, England: S.R. Publishers, Ltd., 1971.

Griffin, Susan. Pornography and Silence: Culture's Revenge Against Nature. New York: Harper and Row, 1981.

Gutherie, E.J. Old Scottish Customs: Local and General. Norwood, Pennsylvania: Norwood Editions, 1974.

Harrison, G. B.. A Jacobean Journal: Being a Record of Those Things Most Talked of During the Years 1603-1606. New York: Macmillan Company, 1941.

Harrison, Michael. The Roots of Witchcraft. Secaucus, New Jersey: The Citadel Press, 1973. 
Headley, P.C. The Life of Mary Queen of Scots. Auburn, New York: Miller, Orton and Mulligan, 1854.

Holmes, Ronald. Witchcraft in British History. London: Frederick Muller Limited, 1974 .

Houston, R.A. and I. D. Whyte. Scottish Society 1500-1800. Cambridge: Cambridge University Press, 1989.

- Scottish Society 1500-1800. Cambridge: Cambridge University Press, 1989.

Hoyt, Charles Alva. Witchcraft 2nd ed. Carbondale: Southern Illinois University Press, 1989.

Hueffer, Oliver Madox. The Book of Witches. Totowa, New Jersey: Rowman \& Littlefield, 1973.

Jahoda, Gustav. ... The Psychology of Superstition. Middlesex, England: Penguin Books, Inc., 1969.

James I. The Daemonologie, in Forme of an Dialogue (1597). [James Carmichael]. Newes from Scotland, Declaring the Damnable Life and Death of Doctor Fian, a Notable Sorcerer, 1591. New York: E.P. Dutton and Comapny, 1924 .

Kitredge, George Lyman. Witchcraft in Old and New England. New York: Russell \& Russell, 1956.

Klaits, Joseph. Servants of Satan: The Age of the Witch Hunts. Bloomington: Indiana University Press, 1985.

Koehler, Lyle. A Search For Power: "The Weaker Sex" in Seventeenth-Century New England. Urbana, Illinois: University of Illinois Press, 1980.

Langbein, John H.. Torture and the Law of Proof: Europe and England in the Ancient Regime. Chicago: The University of Chicago Press, 1979.

Larner, Christina. Enemies of God: The Witch-Hunt in Scotland. Baltimore, Maryland: The Johns Hopkins University Press, 1981.

. "James VI and I and Witchcraft," in Alan G.R. Smith, ed. The Reign of James VI and I. New York: St. Martin's Press, 1977.

- Religion: Politics of Popular Belief. Oxford: Basil Blackwell, 1984 . 
- A Source-Book of Scottish Witchcraft. Glasgow:

University of Glasgow, 1977 .

Witchcraft and Religion: Politics of Popular

Belief. Oxford: Basil Blackwell, 1984 .

Lederer, Wolfgang, M.D.. The Fear of Women. New York:

Grune \& Stratton, 1968 .

Lee, Maurice. Great Britain's Solomon: James VI and I in His Three Kingdoms. Urbana: University of Illinois, 1990 .

Lerner, Gerda. The Creation of Patriarchy. New York: Oxford University Press, 1986.

Lethbridge, T. C.. Witches. Secaucus, New Jersey: The Citadel press, 1962.

Levack, Brian P.. The Witch-Hunt in Early Modern Europe. London: Longman Group, 1987.

Lips, Hilary M. Women, Men, and the Psychology of Power. Englewood Cliffs, New Jersey: Prentice-Hall, Inc., 1981 .

Lyall, Francis. Of Presbyters and Kings: Church and State in the Law of Scotland. Aberdeen, Scotland: Aberdeen University Press, 1980.

Mackenzie, James. The History of Scotland. London: T. Nelson and Sons, 1890 .

Mackie, J.D. A History of Scotland, new and rev. ed. New York: Dorset Press, 1985.

McLachlan, Hugh V. and J. K. Swales. "Stereotypes and Scottish Witchcraft." Contemporary Review 234 (February 1979): 88-94

Marshall, Rosalind K. Virgins and Viragos: A History of Women in Scotland from 1080 to 1980. Chicago: Academy Chicago Ltd., 1983.

Masters, R.E.L. Eros and Evil: The Sexual Psychopathology of Witchcraft. New York: The Julian Press, Inc., Publishers, 1962 .

Mathew, David. James I. London: Eyre and Spottiswoode, 1967. 
Matthews, C.M. English Surnames. New York: Charles Scribner's Sons, 1967.

May, Rollo. Power and Innocence: A Search for the Sources of Violence. New York: W.W. Norton and Comapny, Inc., 1972 .

Melville, James. Memoirs of His Own Life XDXLIX-MDXCIII. Edinburgh: Bannatyne Club, 1827.

- The Autobiography and Diary of Mr. James Melville, with a Continuation of the Diary. Edinburgh: The Woodrow Society, 1842 .

Millett, Kate. Sexual Politics. New York: Avon Books, 1970 .

Mitchison, Rosalind. A History of Scotland. London: Methuen and Co., Ltd. 1970._. European Witchcraft. New York: John Wiley and Sons, Inc., 1969. - European Witchcraft. New York: John Wiley and Sons, Inc., 1969.

Monter, E. William. "The Historiography of European Witchcraft: Progress and Prospects." The Journal of Interdisciplinary History 2 (Spring 1972): 435-51. - European Witchcraft. New York: John Wiley and Sons, Inc., 1969.

Monter, William. Ritual, Myth and Magic in Early Modern Europe. Athens: Ohio University Press, 1983.

Morgan, Robin. The Demon Lover: On the Sexuality of Terrorism. New York: W.W. Norton and Company, 1989.

Murray, Margaret A. The God of the Witches. London: Oxford University Press, 1931.

- The Witch-cult in Western Europe. London: Oxford University Press, 1921.

Newhall, Venetia. The Witch Figure. London: Routledge and Kegan Paul, 1973.

Noddings, Nel. Women and Evil. Berkeley: University of California Press, 1989.

Notestein, Wallace. The Scot in History: A Study of the Interplay of Character and History. New Haven: Yale University Press, 1947. 
Peel, Edgar and Pat Southern. The Trials of the Lancashire Witches: A Study of Seventeenth-Century Witchcraft. New York: Taplinger Publishing Company, 1969.

Pitcairn, Robert. Criminal Trials in Scotland from A.D. 1488 to A.D. 1624 . . . Compiled from the original Records and MSS. 4 vols. Edinburgh: William Tait, 1833 .

Prebble, John. The Lion in the North. Middlesex, England: Penguin Books, 1973 .

Quaife, G.R. Godly Zeal and Furious Rage: The Witch in Early Modern Europe. New York: St. Martin's Press, 1987 .

Robbins, Rossell Hope. Encyclopedia of Witchcraft and Demonology. New York: Peter Nevill, 1959.

Rose, Elliot. A Razor for a Goat: A Discussion of Certain Problems in the History of Witchcraft and Diabolism. Toronto: University of Toronto Press, 1962.

Russe11, Jeffrey Burton. A History of Witchcraft: Sorcerers, Heretics and Pagans. London: Thames and Hudson, 1980 .

- Witchcraft in the Middle Ages. Ithaca: Cornell University Press, 1972.

Sanday, Peggy Reeves. Female Power and Male Dominance: On the Origins of Sexual Inequality. New York: Cambridge University Press, 1981.

Scarre, Geoffrey. Witchcraft and Magic in 16th and 17th Century Europe. Atlantic Highlands, New Jersey: Humanities Press International, Inc., 1988.

Seth, Ronald. Witches and Their Craft. New York: Taplinger Publishing Company, 1967.

Shahar, Shulamith. The Fourth Estate: A History of Women in the Middle Ages, trans. Chaya Galai. London: Methuen, 1983.

Sharpe, Charles Kirkpatrick. A Historical Account of the Belief in Witchcraft in scotland. Detroit, Michigan: Gale Research Company, 1974 .

Simons, G.L. The Witchcraft World. New York: Barnes and Noble, 1974 . 
Smith, Alan G.R. The Reign of James VI and I. New York: St. Martin's Press, 1973.

Stafford, Helen. "Notes on Scottish Witchcraft Cases, 1590-91," in Norton Downs, ed. Essays in Honor of Conyers Read. Chicago: University of Chicago Press, 1953.

Steeholm, Clara and Hardy. James I of England: The Wisest Fool in Christiandom. New York: Covice, Friedi Publishers, 1938.

Summers, Montague. The History of Witchcraft and Demonology. New Hyde Park, New York: University Books, 1966 .

- The Malleus Maleficarum of Heinrich Kramer and James Sprenger. New York: Dover Publications, Inc., 1971 .

Thomas, Keith. "The Relevance of Social Anthropology to the Historical Study of English Witchcraft" in Mary Douglas, ed. Witchcraft Confessions and Accusations. London: Tavistock Publicatons, 1970 .

- Religion and the Decline of Magic. New York: Charles Scribner's Sons, 1971 .

Turner, E.S. May It Please Your Lordship. London: Michael Joseph, 1971.

Van Vuuren, Nancy. The Subversion of Women: As Practiced by Churches, witch-Hunters, and other sexists. Philadelphia: Westminster Press, 1973.

Waddell, Helen. The Wandering Scholars. New York: Barnes and Noble, 1968 .

Walker, Barbara G. The Crone: Woman of Age, Wisdom, and Power. San Francisco: Harper and Row, Publishers, 1985.

Warner, George F, ed. The Library of James VI 1573-1583: From a Manuscript in the hand of Peter Young, His Tutor. Edinburgh: University Press, 1893.

Webster, David. A Collection of Rare and Curious Tracts on Witchcraft and the Second Sight. Edinburgh: Thomas Webster, 1820 . 
West, Robert H. Reginald Scot and Renaissance Writings on Witchcraft. Boston: Twayne Publishers, 1984.

Weyer, Johann. De Praestigiis Daemonum. (1563) Book III, Chapters iij-iv, trans. by E. Bournville in E. William Monter. European Witch. New York: John Wiley \& Sons, Inc., 1969. 37-47.

Whittington, G. and I.D. Whyte, eds. An Historical Geography of Scotland. London: Academic Press, 1983.

Williams, Ethel Carleton. Anne of Denmark: Wife of James VI of Scotland; James I of England. London: Longman Group Limited, 1970 .

Williams, Selma R. and Pamela J. Williams. Riding the Night Mare: Women and Witchcraft. New York: Antheneum, 1978 .

Willson, D.H. King James VI and I. London: Bedford Historical Series, 1956.

Woods, William. A Casebook of Witchcraft: Reports, Depositions, Confessions, Trials, and Executions for Witchcraft During a Period of Three Hundred Years. New York: G.P. Putnam's Sons, 1974.

Wormald, Jenny. Court, Kirk, and Community: Scotland 1470-1625. Toronto: University of Toronto Press, 1981 .

Yates, Frances A. The Occult Philosophy in the Elizabethan Age. London: Routledge and Kegan Paul, 1979 .

Zweig, Stefan. Mary Queen of Scotland and the Isles. New York: The Viking Press, 1935. 